\title{
Ichthyoplankton assemblages at three shallow seamounts in the South West Indian Ocean
}

\author{
Harris Shael A. ${ }^{1,{ }^{*}}$, Noyon Margaux ${ }^{2}$, Marsac Francis ${ }^{3,4}$, Vianello Patrick ${ }^{2}$, Roberts Michael J. ${ }^{2,5}$
}

1 Zoology Department, Nelson Mandela University, Port Elizabeth, South Africa

2 Ocean Science \& Marine Food Security, Nelson Mandela University, Port Elizabeth, South Africa

${ }^{3}$ MARBEC, Univ. Montpellier, CNRS, Ifremer, IRD, Sète, France

${ }^{4}$ Department of Biological Sciences and Marine Research Institute/ICEMASA, University of Cape Town, Cape Town, South Africa

${ }^{5}$ National Oceanography Centre, Southampton, United Kingdom

*Corresponding author : Shael A. Harris, email address : shaelh@worldonline.co.za

\begin{abstract}
:
The composition and spatial variability of ichthyoplankton assemblages were investigated at three shallow seamounts between latitudes $19^{\circ} \mathrm{S}$ and $33^{\circ} \mathrm{S}$ in the South West Indian Ocean (SWIO) - La Pérouse $(60 \mathrm{~m})$, an unnamed pinnacle south of Madagascar, referred to hereafter as MAD-Ridge $(240 \mathrm{~m})$, and the Walters Shoal seamount ( $18 \mathrm{~m}$ ). In all, 299 larvae ( 23 families, 54 species) were present at La Pérouse, 964 larvae (58 families and 127 species) at MAD-Ridge, and 129 larvae (9 families, 24 species) at the Walters Shoal. Larvae of mesopelagic fish in the families Myctophidae and Gonostomatidae were the most dominant at all three seamounts. All developmental stages were present at each seamount, suggesting the larval pelagic phase of certain species occurs at the seamounts. A 'seamount effect' was detected only at MAD-Ridge where larval fish densities were significantly higher at summit stations. Overall, MAD-Ridge had much higher densities of fish larvae (157.0 larvae $100 \mathrm{~m}-3)$ than La Pérouse (31.1 larvae $100 \mathrm{~m}-3)$ and the Walters Shoal (9.6 larvae $100 \mathrm{~m}-3)$. Our study demonstrates that ichthyoplankton communities at shallow seamounts in the SWIO are more influenced by their location relative to a landmass, and to oceanographic features such as currents, mesoscale eddies and water masses than the seamount latitude and topography itself.
\end{abstract}

Keywords : Larval fish assemblages, Seamount effect, Latitudinal differences, Larval developmental stages, Habitat association, Mesoscale dipole eddy 
Seamounts are important marine habitats that sustain benthic and pelagic communities

(Morato et al., 2010; Clark et al., 2012; Garcia et al., 2013; Kvile et al., 2014; Rogers, 2018),

but the pathways and underlying mechanisms are poorly understood and mostly based on theory. There is therefore a need to examine factors that influence seamount communities, and importantly, how these differ between seamounts (Morato et al., 2010). Diekmann et al. (2006) points out that biological investigations at seamounts are difficult because of their remoteness, meaning that sampling is often restricted both spatially and temporally.

Nonetheless, many aspects of seamount ecology have advanced over the past 25 years, but given the large numbers of seamounts, estimated to be around 14000 globally, there are many that remain unknown or poorly understood (Rogers, 2018). Stocks et al. (2012) suggested that, to gain a better understanding of seamount communities, research should focus on environmental drivers affecting species composition and diversity, and how these affect different seamounts.

In a review of seamount plankton dynamics, Genin and Dower (2007) reported that despite an abundance of adult fish species over seamounts, little is known about the early life history stages of those fish, and whether they are distinct communities or an extension of typical oceanic assemblages. Yet the number of fish larvae studies is steadily growing. For example, larval fish assemblages have been explored at some seamounts in the north Atlantic (Nellen, 1973; Belyanina, 1984; Gordina, 1991; Nellen and Ruseler, 2004; Diekmann et al., 2006; Arkhipov and Mamedov, 2008; Hanel et al., 2010; Vinogradov et al., 2014), the Central East Atlantic (Arkhipov et al., 2004), the South West Atlantic (Bonecker et al., 2006; Stocco and Jeux, 2015), and the Central North Pacific (Boehlert, 1988). However, in the 
undertaken, namely by Belyanina (1993). This focused on the Saya de Malha Bank

(Mascarene) and the Walters Shoal seamount in the SWIO.

The dispersal of fish larvae is not only affected by species traits such as spawning mode and pelagic larval duration (PLD), but also ocean currents and other mesoscale features such as fronts and eddies that advect or retain fish larvae (Leis et al., 2013). For fish communities at isolated seamounts to be self-sustaining, it is essential that there is larval retention around a seamount. In the biological realm, a 'seamount effect' is defined by higher or lesser species density, species diversity, or habitat association at the seamount summit relative to farther away (Boehlert and Mundy, 1993; Dower and McKas, 1996; Sobrinho-Gonçalves and Cardigo, 2006; Stocco and Joyeux, 2015). These last four studies reported that this seamount effect can be attributed to factors such as retention of zooplankton and/or fish larvae above a seamount by processes such as a Taylor column, upwelling (enhancing local primary productivity), disruption of diel vertical migration patterns by the topography, and habitat preferences. A Taylor column is a semi-stationary eddy that develops around a submarine topographic feature such as a seamount under certain ambient current conditions, and is capable of retaining zooplankton around the summit (Boehlert and Genin, 1987; Boehlert, 1988). However, the situation is more complex. For example, Dower and MacKas (1996) found that biological factors such as differential growth, reproduction, mortality, predation and migration of the zooplankton community also played a role in the seamount effect near Cobb Seamount. Not all seamounts have Taylor columns, though, because the physics depends on factors such as seamount shape, depth, water column stratification and the ambient current (Chapman and Haidvogel, 1992).

In the context of the global ocean, the biodiversity of seamounts in the Indian Ocean is particularly poorly known. This provided motivation for the Southern Indian Ocean Seamounts Project in 2009, the first large-scale expedition of its kind (Rogers et al., 2017) in the region. The 2009 campaign explored the physical oceanography and its influence on the 

pelagic communities of six seamounts distributed along the South West Indian Ridge. In 2016, a further substantial seamount investigation was launched in the SWIO in the form of the French-South African MAD-Ridge project (Roberts et al., 2020). Based around ship surveys using the R/Vs Antea and Marion Dufresne, the work focused on three shallow seamounts across a latitudinal gradient from 19 to $33^{\circ} \mathrm{S}$ with a range of dynamic environments (Vianello et al., 2020a). Two of the seamounts, the Walters Shoal (18 m) and an unnamed seamount just south of Madagascar (240 m; hereafter referred to as MAD-Ridge) are on the Madagascar Ridge - a $1300 \mathrm{~km}$ rocky extension of the Madagascar landmass. The third seamount, La Pérouse $(60 \mathrm{~m})$, is east of Madagascar on the Madagascar abyssal plain.

This study, as part of the MAD-Ridge project, examines the biophysical coupling in relation to the composition and spatial variability of ichthyoplankton assemblages around the Walters Shoal, MAD-Ridge and La Pérouse seamounts. We test the null hypotheses that (a) there is no difference in larval fish composition and spatial variability between the three seamounts (i.e. no latitudinal effect), (b) there is no seamount effect with respect to larval fish densities, species diversity, developmental stages and habitat association groups (OFF/ON the seamount), and (c) mesoscale eddy activity does not influence larval fish density patterns.

\section{Material and Methods}

\subsection{Study sites}

The three shallow seamounts in this study, La Pérouse (60 m), MAD-Ridge (240 m) and Walters Shoal $(18 \mathrm{~m})$, are distributed between 19 and $33^{\circ} \mathrm{S}$ with very different dynamic environments. The La Pérouse seamount is located at $19^{\circ} 43^{\prime} \mathrm{S}, 54^{\circ} 10^{\prime} \mathrm{E}$ some $160 \mathrm{~km}$ 

northwest of Réunion (Fig. 1a). It has a crescent-shaped summit around 55-60 m and is 10 km long with steep sides (Fig. 1b). La Pérouse is a volcano rising from the Madagascar abyssal plain in the subtropical region that is strongly influenced by the South Equatorial Current (SEC). Mesoscale activity (eddies) there tend to be low (Pous et al., 2014; Vianello et al., 2020a) (Fig. 1a). The MAD-Ridge seamount is $240 \mathrm{~km}$ south of Madagascar at $27^{\circ} 29^{\prime} \mathrm{S}$, $46^{\circ} 16^{\prime} \mathrm{E}$, and has a conical summit at a depth of $240 \mathrm{~m}$ with north-south dimensions of $33 \mathrm{~km}$ and $22 \mathrm{~km}$ east-west (Fig. 1b). That region has high mesoscale activity with regular eddies originating from where the East Madagascar Current (EMC) separates from the shelf (de Ruijter et al., 2004; Vianello et al., 2020a) (Fig. 1a). The MAD-Ridge seamount is included in the Southern Madagascar Ecologically or Biologically Significant Area (EBSA) because the waters are highly productive and critical feeding grounds for migratory seabirds and cetaceans (CBD, 2016). Walters Shoal is much farther south on the Madagascar Ridge, some $855 \mathrm{~km}$ south of Madagascar at $33^{\circ} 12^{\prime} \mathrm{S}, 43^{\circ} 54^{\prime} \mathrm{E}$, in a temperate region. That feature too has a circular summit with an area of some $400 \mathrm{~km}^{2}$. The centre has collapsed forming a caldera at an average depth of $50 \mathrm{~m}$ and a highpoint of $18 \mathrm{~m}$ deep on the one side. Mesoscale dynamics as reflected by the sea level anomaly (SLA) are low and consequently currents are weak in the region (Pollard and Read, 2017; Vianello et al., 2020a) (Fig. 1a, b). Walters Shoal has been exploited by fisheries in the past (Shotton, 2006) but is now part of the Walters Shoal EBSA (CBD, 2016), because certain shallow-water fish fauna are endemic to some parts of the seamounts (Collette and Parin, 1991).

\subsection{Field sampling and laboratory analysis}

Oceanographic cruises using the French R/V Antea were undertaken to La Pérouse (doi: 10.17600/16004500) between 15 and 30 September 2016 and MAD-Ridge (dois: 10.17600/16004800 and 10.17600/16004900) between 8 November and 14 December 2016. 
Marion Dufresne II from 26 April to 18 May 2017.

\subsubsection{Hydrological Stations}

The locations of all stations for each of the three seamounts are shown in Fig. $1 \mathrm{~b}$. Temperature $\left({ }^{\circ} \mathrm{C}\right)$, salinity $\left(\mathrm{g} \mathrm{kg}^{-1}\right)$, fluorescence and depth $(\mathrm{m})$ were measured using a SeaBird 911plus CTD rosette system equipped with a Wetlabs ECO FL fluorometer. This was lowered to a depth of $\sim 1000 \mathrm{~m}$ for each cruise. Chlorophyll- $a$ (Chl-a) concentrations (mg $\mathrm{m}^{-3}$ ) were calibrated using High Performance Liquid Chromatography (HPLC) samples measured at discrete depths. The Integrated Chl-a concentration was calculated as the sum of Chl-a at each 1-m depth bin in the upper $200 \mathrm{~m}$. Depth of the deep Chl-a maximum (DCM, in m) was calculated from CTD data. The mixed layer depth (MLD) was determined according to de Boyer-Montégut et al. (2004), using a change of $0.08 \mathrm{~kg} \mathrm{~m}^{-3}$ from a depth of $10 \mathrm{~m}$. Temperature-Salinity (T-S) plots of water masses in the upper $500 \mathrm{~m}$ were produced using Ocean Data View software (ODV V5.1.5) (Schlitzer, 2018; Ocean Data View, https://odv.awi.de, 2018). The T-S characteristics of each water mass were obtained from de Ruijter et al. (2004), Read and Pollard (2017), and Makarim et al. (2019), and are represented in Fig. 2. A seven-day sea surface level anomaly (SLA) product at $14^{\circ}$ resolution was used to monitor the eddy activity in the region of the MAD-Ridge seamount during the period prior to, during and after the MAD-Ridge cruise (Vianello et al., 2020b). Variations in SLA values correspond to anticyclonic or cyclonic eddies, respectively. Eddies were tracked using the algorithm developed by Chelton et al. (2007), based on a SLA closed contours threshold (Vianello et al., 2020b).

Mesoscale eddy classification was only applied to the MAD-Ridge seamount, because only that feature experienced strong dipole activity during sampling: 'Cyclone' (abbreviated 
C) included stations 2 and 4 within the cyclone; 'Anticyclone' (abbreviated AC) included stations $8,9,10,12,16,18,19,20,21,22,23,24$ and 25 within the anticyclone; 'Transition dipole' (abbreviated T-D) included stations 6 and 7 located between the cyclone and anticyclone; 'Transition-AC' (abbreviated T-AC) included stations 14 and 27 on the eastern border of the AC (Annasawmy et al., 2020). All stations were also classified according to water depth with appropriate abbreviations: summit (SU, <350 m), slope (SL, 350-1500 m), and deep-sea (DS, > $1500 \mathrm{~m}$ ). 'ON' category refers to SU and SL (i.e. within 10 nautical miles - nmi - of the summit), and 'OFF' to 'DS'. The deep sea/OFF stations were the control stations in terms of testing a seamount effect.

\subsubsection{Larval fish sampling}

At each seamount, ichthyoplankton samples were collected at the same location and time as selected CTD stations. Hence, the total sampling timespan ranged from 7 to 9 days, i.e. La Pérouse (21-27 September 2016), MAD-Ridge (14-22 November 2016) and Walters Shoal (4-13 May 2017) - see Table 1. For all samples, a Bongo net comprising $500 \mu \mathrm{m}$ mesh and a flowmeter to measure the volume of seawater sampled was towed obliquely from the surface to $500 \mathrm{~m}$ at an average speed of 1-2 knots (Fig. 1b). Being shallow, the Walters Shoal seamount was only sampled around the outside of the caldera (on the slopes). Also, owing to ships' time constraints, there were no OFF (control) stations at the Walters Shoal. All ichthyoplankton samples were preserved with buffered formalin to a final concentration of $4 \%$.

In the laboratory, zooplankton samples were poured into a measuring cylinder and left to settle for $24 \mathrm{~h}$, after which the settled volume was recorded (ml). Settled zooplankton volume was then expressed as $\mathrm{ml} \mathrm{m}^{-3}$ by dividing the settled volume with the volume of seawater filtered. Fish larvae were then separated from the samples and identified to species level 

where possible using a Zeiss Stemi 305 stereo microscope. For identification purposes the following references were used: Moser (1996), Okiyama (1988), Olivar and Beckley (1995, 1997), Olivar et al. (1999), Leis and Carson-Ewart (2000). 'Unidentified' larvae were either damaged or at early preflexion developmental stages, except for the family Myctophidae, where such larvae were classified as 'Myctophid unidents'.

Body length (BL - snout to tip of notochord) of larvae was measured to the nearest 0.5 $\mathrm{mm}$ using the microscope graticule. Developmental stage was noted according to Leis and Carson-Ewart (2000) with the following criteria: $\operatorname{Pr}$ (preflexion) $=$ hatching to start of upward flexion of the notochord; Fl (flexion) = upward bending of the notochord tip; Po (postflexion) = formation of the caudal fin to attainment of full external meristics. For leptocephali, the larval forms of eels in the families Elopiformes, Anguilliformes and Notocanthiformes (Smith, 1979), the abbreviation 'Le" is used. Molidae (sunfish) do not develop a typical caudal fin, but rather a "clavus (pseudo-caudal)" (Leis, 1977). Hence, the following criteria were used in this study to describe the developmental stages of those larvae: Nh (newly hatched) $\mathrm{BL}=1.0-1.7 \mathrm{~mm}$, similar to a late final-stage embryo; Dg (differential growth phase) $\mathrm{BL}=1.8-3.8 \mathrm{~mm}$, during which the jaws, snout and posterior clavus develop (adapted from Leis, 1977).

Larval densities were calculated as the number of larvae per $100 \mathrm{~m}^{3}\left(\right.$ larvae $100 \mathrm{~m}^{-3}$ ), and represent the larval fish assemblage in the upper $500 \mathrm{~m}$ of the water column. Each family/species was placed in a habitat association category, according to the adult preferred habitat (Smith and Heemstra, 1986; Moser, 1996), namely: Oceanic = beyond the $200 \mathrm{~m}$ depth contour (epipelagic, mesopelagic, benthopelagic); Neritic $=$ continental shelf up to 200 $\mathrm{m}$ (epipelagic, reef, benthic).

\subsection{Data and Statistical Analyses}


198

199

200

201

202

203

204

205

206

207

208

209

210

211

212

213

214

215

216

217

218

Species diversity was determined using the PRIMER V7 (V7.0.13) PERMANOVA+ software package (Anderson et al., 2008; Clarke and Gorley, 2015), with the Analyse > DIVERSE menu. Data were pre-treated with a fourth-root transformation of the species data. The indices S (total number of species in each sample) and the Shannon-Wiener Diversity $\left(\log\right.$ base e) $\left(\mathrm{H}^{\prime}=-\Sigma(p i \ln (p i))\right.$ were calculated. The non-parametric test Kruskal-Wallis test was used to test for significant differences in the number of species (S), Shannon-Wiener Diversity (H'), larval fish density, developmental stages (preflexion, flexion and postflexion), and habitat association groups (oceanic epipelagic, oceanic mesopelagic and benthic, neritic reef, epipelagic and benthic) between the three seamounts ("latitude") and at ON/OFF stations ("seamount effect"). This was followed by a post hoc Dunn test using the software R (version 3.6.1). As Walters Shoal only had ON (slope and summit) stations, it is not included in the OFF vs. ON stations statistical comparison.

\subsubsection{Multivariate}

Multivariate analyses were similarly undertaken using the PRIMER V7 (V7.0.13) PERMANOVA+ software package (Anderson et al., 2008; Clarke and Gorley, 2015). Environmental data were $\log (\mathrm{x}+1)$ transformed according to Draftsman Plots, which indicate which environmental variables require transformation, then normalised so that all variables have comparable scales prior to further analysis. The environmental variables assessed were bottom depth (m), DCM, MLD, mean temperature in the top $200 \mathrm{~m}$ (T200) $\left({ }^{\circ} \mathrm{C}\right)$, mean salinity in the top $200 \mathrm{~m}(\mathrm{~S} 200)\left(\mathrm{g} \mathrm{kg}^{-1}\right)$, integrated Chl-a $200 \mathrm{~m}\left(\mathrm{mg} \mathrm{m}^{-3}\right)$, and settled zooplankton volume $\left(\mathrm{ml} \mathrm{m}^{-3}\right)$. The top $200 \mathrm{~m}$ of the water column were used because "most open ocean biomass, including phytoplankton, zooplankton, and nekton, is found within $~ 200$ m of the ocean surface" (Sigman and Hain, 2012). To determine which variables to include in 
further analyses, we used the Spearman Rank Correlation from the Draftsman Plots. This

223 determined which variables were strongly correlated with each other $\left(\mathrm{R}^{2}>0.8\right)$, and

224

225 consequently, were excluded from the analysis. Six variables were selected: Bottom depth, DCM, MLD, T200, integrated Chl-a $200 \mathrm{~m}$ and zooplankton settled volume.

Prior to multivariate analysis on the biological data, unidentified larvae and those taxa contributing to $<5 \%$ of overall density were excluded from the analysis. Data were fourthroot transformed prior to further analysis based on 'Shade Plot', a feature in PRIMER V7 that illustrates where there is sufficient representation of rare species with each level of transformation (as indicated by the level of shading: light to dark according to low to high densities, respectively). Non-metric multidimensional scaling (nMDS) ordination displayed groupings of stations according to the factor 'latitude', based on the resemblance matrix of the biological data. Similarity percentage analysis (SIMPER) was then used to determine which species contributed most to the observed patterns.

A distance-based linear model (DISTLM) analysed the relationship between the species patterns (nMDS) and key environmental variables, providing P-values for testing the null hypothesis (Anderson et al., 2008). A distance-based redundancy analysis (dbRDA) graphic was generated from the DISTLM to visualise the given model.

A one-way Analysis of Similarity (ANOSIM) non-parametric test was done to test the significance of the effect dipole classification for MAD-Ridge only (9999 permutations). The Canonical analysis of principal coordinates (CAP) routine was used because it discriminates groups from the resemblance matrix that are identified by the ANOSIM significant factor, with canonical correlations indicating the strength of the association between the multivariate data and the group differences (Anderson et al., 2008).

\section{Results}

\subsection{Oceanographic conditions}


249 Walters Shoal seamount surveys are given by Vianello et al. (2020b), Marsac et al. (2020)

250 and Demarcq et al. (2020) respectively. T-S plots shown in Fig. 2 provide information on

251 possible sources of water masses at each of the three seamounts during the study period. At

252 La Pérouse, the upper $100 \mathrm{~m}$ consisted of tropical surface water (TSW) with temperatures of $22-23^{\circ} \mathrm{C}$, some $4-5^{\circ} \mathrm{C}$ warmer than the deeper $(100-300 \mathrm{~m})$ subtropical surface waters (STSW) (Fig. 2a). MAD-Ridge similarly had both TSW and STSW water masses in the upper $300 \mathrm{~m}$, but surface temperatures were warmer than at La Pérouse, reaching $\sim 25^{\circ} \mathrm{C}$. In addition, higher salinities in the temperature range $15-20^{\circ} \mathrm{C}$ at stations 22,23 and 24 signalled the presence of the anticyclone (AC) part of a dipole eddy (Fig. 2b; see Vianello et al., 2020b, for dipole details). Walters Shoal was different from the other two seamounts with the absence of TSW, and was instead influenced by STSW and South Indian Central Water $(\mathrm{SICW})$ in the upper $300 \mathrm{~m}$ with lower temperatures $\left(17-20^{\circ} \mathrm{C}\right)$ and higher salinities $(35.5 \mathrm{vs}$. $\sim 35.2 \mathrm{~kg} \mathrm{~g}^{-1}$ ) than La Pérouse and MAD-Ridge (Fig. 2c). Between 300 and $500 \mathrm{~m}$, the water column was characterised by Antarctic Intermediate Water (AAIW) at all three seamounts.

As shown in Fig. 3, an intense dipole eddy passed through the MAD-Ridge seamount study area between 29 October to 24 December 2016, with a negative sea level anomaly (SLA) of $\sim-20-50 \mathrm{~cm}$ for the cyclone and positive SLA of $\sim+20-40 \mathrm{~cm}$ for the anticyclone eddy. As shown in Vianello et al., (2020b; Fig. 14c), this is near the maximal limit of eddy intensity. As a measure of eddy activity, the Eddy Kinetic Energy (EKE) in the MAD-Ridge study area is on average greater $\left(2.8-3.0 \mathrm{~cm}^{2} \mathrm{~s}^{-1}\right)$ than to the north at La Pérouse $(2.2-2.4$ $\left.\mathrm{cm}^{2} \mathrm{~s}^{-1}\right)$ and to the south at Walters Shoal where the EKE is generally low $\left(1.6-1.8 \mathrm{~cm}^{2} \mathrm{~s}^{-1}\right)$ (see Fig. 1a, Vianello et al., 2020b). The high EKE at MAD-Ridge indicates that dipole eddies are a frequent feature of the oceanography in this area. 
275 were similar at both MAD-Ridge (58 and $116 \mathrm{~m}$, respectively) and La Pérouse (62 and 107 $\mathrm{m}$, respectively) whereas Walters Shoal showed shallowest MLD and DCM depths (37 and $38 \mathrm{~m}$, respectively). The mean temperature within the top $200 \mathrm{~m}$ was similar at MAD-Ridge $\left(22.66 \pm 0.90{ }^{\circ} \mathrm{C}\right)$ and La Pérouse $\left(21.94 \pm 0.17^{\circ} \mathrm{C}\right)$, but lower at Walters Shoal $(18.21 \pm 0.37$ $\left.{ }^{\circ} \mathrm{C}\right)$. Walters Shoal was more saline and had a higher integrated Chl-a concentration within the top $200 \mathrm{~m}$, relative to La Pérouse and MAD-Ridge. Settled zooplankton volume was twice as much at MAD-Ridge than at the other two seamounts, with a mean of $0.056( \pm$ $0.021) \mathrm{ml} \mathrm{m}^{-3}$.

\subsection{Composition of larval fish assemblages}

285

286

287

In all, 964 fish larvae, representing 58 families and 127 species, were present at the MADRidge seamount (Table 3). Fewer larvae were collected at the La Pérouse and Walters Shoal seamounts, with 299 (23 families, 54 species) and 129 (9 families, 24 species) larvae, respectively. As anticipated, the larvae of oceanic mesopelagic fish in the families Myctophidae and Gonostomatidae dominated at all three seamounts, although interestingly the larvae of neritic taxa were present at MAD-Ridge (16.2\%) and La Pérouse (3.8\%) (Table 3). At MAD-Ridge these neritic taxa were either epipelagic (8.9\%), reef- (6.2\%), or benthic(1.1\%) associated. Myctophids (lanternfish) constituted $46.9 \%$ of the catch at both La Pérouse and MAD-Ridge, and 35.7\% at Walters Shoal. Gonostomatids (bristlemouths) were more abundant than myctophids at Walters Shoal, where they made up $37.8 \%$ of the total catch.

The most abundant myctophid species at La Pérouse were Symbolophorus evermanni (3.9\%), and Diaphus sp.2 (3.4\%). At MAD-Ridge, the dominant species were Diaphus mollis (2.2\%), Lampadena luminosa (1.9\%) and Benthosema suborbitale (1.4\%). At Walters Shoal 

most abundant mesopelagic gonostomatid at La Pérouse and MAD-Ridge was Cyclothone alba $(23.7 \%$ and $7.1 \%$, respectively), but Cyclothone pseudopallida (36.5\%) was more abundant at Walters Shoal. Other families representing $\geq 5 \%$ of the total catch at MAD-Ridge included the neritic taxa Bregmacerotidae (8.0\%; Bregmaceros atlanticus, B. macclellandii, B. nectabanus), at La Pérouse it was the Phosichthyidae (8.3\%; Vinciguerria lucetia), and at Walters Shoal it was the Melamphaidae (11.4\%; Melamphaes sp.1) and the Sternoptychidae (5.8\%; Argyropelecus lychnus, A. sladeni). The second most abundant family at MAD-Ridge was the oceanic (epipelagic) Molidae, represented by the species Ranzania laevis (slender sunfish), with a total of 109 specimens constituting $12.5 \%$ of the total catch (Table 3 ).

\subsection{Spatial variability of larval fish assemblages}

\subsubsection{Latitudinal patterns}

312 Overall, MAD-Ridge had much higher total densities of fish larvae (157.0 larvae $\left.100 \mathrm{~m}^{-3}\right)$, than La Pérouse (31.1 larvae $100 \mathrm{~m}^{-3}$ ) and Walters Shoal (9.6 larvae $100 \mathrm{~m}^{-3}$ ) (Table 3). Larval fish densities at La Pérouse were highest at slope stations $24\left(6.8\right.$ larvae $\left.100 \mathrm{~m}^{-3}\right)$ and 6 (5.3 larvae $100 \mathrm{~m}^{-3}$ ), with only 0.44 larvae $100 \mathrm{~m}^{-3}$ at deep-sea station 1 about $10 \mathrm{nmi}$ north of the summit (Fig. 4). MAD-Ridge similarly had high larval fish densities at shallow summit station $8\left(15.7\right.$ larvae $\left.100 \mathrm{~m}^{-3}\right)$ and $22\left(16.5\right.$ larvae $\left.100 \mathrm{~m}^{-3}\right)$, but the greatest density was at station 18 (17.8 larvae $\left.100 \mathrm{~m}^{-3}\right)$, which is a deep-sea station $20 \mathrm{nmi}$ south of the summit. Very low densities of fish larvae were collected at Walters Shoal relative to La Pérouse and MADlarvae $100 \mathrm{~m}^{-3}$. 
323 latitude, i.e. seamount (stress level of 0.12) (Fig. 5a). The SIMPER analysis shows that the main species discriminating between La Pérouse and MAD-Ridge were $R$. laevis, Myctophid unidents and C. alba; between La Pérouse and Walters Shoal seamounts (mid-latitude) it was Shoal it was $R$. laevis, C. pseudopallida and H. proximum (Table 4, Fig. 5b). Note that the average dissimilarity (aveDiss) value in Table 4 is the best indicator of which species contribute the most to the differentiation of the groups shown in the nMDS (Fig. 5a) analyses, e.g. C. alba has a Diss/SD value of 2.23, indicating that it is a good indicator for La Perouse relative to Walters Shoal (but not MAD-Ridge), in this particular study.

\subsubsection{ON/OFF seamount patterns}

The number of species (S) and species diversity (H') was significantly lower at Walters Shoal than at MAD-Ridge (KW and Dunn test, $\mathrm{p}<0.001$ ), but was similar between La Pérouse and MAD-Ridge. No significant differences between OFF (deep sea) and ON (slope and summit) stations at La Pérouse and MAD-Ridge were found (Fig. 6a, b). MAD-Ridge, all stations considered, had significantly higher larval fish densities than both La Pérouse and Walters Shoal (KW, LP vs. MR p < 0.05; MR vs. WS p < 0.001) (Fig. 6c). At La Pérouse there was no significant difference in larval fish densities between ON and OFF (KW, $p=0.327)$, but at MAD-Ridge there were significantly greater densities of fish larvae ON the seamount (KW, $\mathrm{p}=0.028$, Fig. 6c). Preflexion, flexion and postflexion developmental stages were not different between latitudes, except for Walters Shoal, which had significantly less of all three stages than MAD-Ridge $(\mathrm{p}<0.001)$ (Fig. 6d, e, f). This is directly a consequence of the total number of fish larvae being significantly more at MAD-Ridge (Fig. 6c). Only densities of preflexion larvae were significantly higher at $\mathrm{ON}$ stations (26.5 Pr larvae $100 \mathrm{~m}^{-3}$ ) relative to 
OFF stations (22.3 Pr larvae $100 \mathrm{~m}^{-3}$ ) at MAD-Ridge ( $\left.\mathrm{p}<0.001\right)$ (Fig. 6d). When considering habitat association groups, only oceanic mesopelagic + benthic group had significantly greater densities at ON stations at MAD-Ridge (Fig. 6g, h, i) $(\mathrm{p}<0.001)$.

\subsection{Environmental variables influencing larval fish spatial patterns}

The distance-based linear model (DISTLM) marginal tests, which analysed the relationship between the six key environmental variables and the species patterns (nMDS; Fig. 5), showed that four of the six environmental variables in the model, i.e. DCM, T200, integrated Chl-a $200 \mathrm{~m}$ and zooplankton settled volume, when considered alone, explained a significant proportion of the variation in larval fish patterns $(\mathrm{P}<0.05)$ (Table 5). However, when all variables were combined, the best fit model could only produce an $\mathrm{R}^{2}$ of 0.28 .

The distance-based redundancy analysis (dbRDA) visualises the DISTLM model with the first two axes capturing $76.6 \%$ of the variability explained by the fitted model, but only $21.8 \%$ of the total variation in the data (Fig. 7). On the first dbRDA1 axis (17.7\% of the total variation), Walters Shoal (ML) was clearly grouped together, and opposed to MAD-Ridge (ST). La Pérouse (T) was not well discriminated by the first axis, but showed slight differences from the other two seamounts on the second dbRDA2 axis $(4.1 \%$ of total variation). The first dbRDA1 axis explains $62.3 \%$ of the fitted model and is strongly related to T200 and DCM at La Pérouse and MAD-Ridge, whereas Integrated Chl-a 200m impacts the mid-latitude/Walters Shoal seamounts (Fig. 7). The second axis explains just $14.3 \%$ of the fitted model, with bottom depth and zooplankton settled volume seeming to be the main opposing factors affecting this axis.

As seen in Fig. 8, distinct groupings of fish larvae are evident at MAD-Ridge when the mesoscale eddy classification is used as a factor (ANOSIM one-way test significant, $\mathrm{R}=$ 0.64). The first axis of the CAP1 shows that the larval fish assemblage in the cyclonic eddy 
374 distinguishes the larval fish assemblages in the transition zones (T-D, T-AC) from the stations in the anticyclonic (AC) and cyclonic parts (C). The canonical correlations for CAP1 and CAP2 are high, indicating a strong association between larval fish groupings and the different areas of the eddy dipole feature $\left(\delta_{1}=0.92, \delta_{2}=0.80\right)$. The species that characterise the differences among groups (Spearman Rank correlation > 0.3) are displayed as vectors in Fig. 8, with the neritic epipelagic B. atlanticus and B. nectabanus being more abundant in the cyclonic part of the dipole eddy. The myctophid $L$.alatus characterises stations 6,7 and 14 , which were in transition areas of the eddy. The majority of the anticyclonic stations are characterised by $C$. alba and Myctophid unidents.

\section{Discussion}

\subsection{Larval fish assemblages at seamounts}

This study has shown that the composition of larval fish communities at all three seamounts, La Pérouse, MAD-Ridge and Walters Shoal, is characterised by general oceanic assemblages, with the mesopelagic families Myctophidae and Gonostomatidae dominating. Interestingly, despite a $14^{\circ}$ difference between the Walters Shoal and La Pérouse, a latitudinal gradient in species diversity of the fish larvae was not evident. These are not unusual findings. Many ichthyoplankton surveys in the vicinities of seamounts have shown general domination by typical oceanic mesopelagic taxa in the families Myctophidae and Gonostomatidae, regardless of their latitudinal position (e.g. Boehlert, 1988; Belyanina, 1993; Boehlert and Mundy, 1993; Nellen and Ruseler, 2004; Diekmann et al., 2006; Sobrinho-Gonçalves and Cardigos, 2006; Arkhipov and Mamedov, 2008; Hanel et al., 2010; Stocco and Joyeux, 2015). In fact, only a few studies have found larvae of topographically associated species to 
be more abundant at seamounts than in the surrounding ocean, indicating that specialized

400 ichthyoplankton assemblages are not common around seamounts (Boehlert, 1988; Boehlert

401

402

403

404

405

406

407

408

409

410

411

412

413

414

415

416

417

418

419

420

421

422

423

424 and Mundy, 1993). Moreover, at the MAD-Ridge seamount, larval stages of neritic reefassociated species were present (e.g. Acanthuridae - Naso sp., Apogonidae - Apogon sp., Labridae - Cirrhilabrus sp., Lutjanidae, Serranidae - Anthias sp.), which can only be explained by a strong connection to the shelf waters of Madagascar, because this seamount is about $240 \mathrm{~km}$ from the coast. Other seamounts near shelf areas have found some representation of neritic reef-associated species (e.g. Nellen and Ruseler, 2004; Bonecker et al., 2006; Stocco and Joyeux, 2015). In the case of the MAD-Ridge project, Crochelet et al. (2020), using a Lagrangian model, demonstrated a greater connectivity between the east coast of Madagascar and the MAD-Ridge seamount than between Mauritius/ Réunion and the La Pérouse seamount - hence explaining the greater species diversity of fish larvae at the subtropical MAD-Ridge than at the tropical La Pérouse seamount. The Walters Shoal seamount, on the other hand, is the most isolated, so reflecting only a typical oceanic community with low species diversity of fish larvae. This would imply that ichthyoplankton at seamounts is more influenced by its relative position to continental shelf areas than to latitudinal position.

Of the three seamounts studied here, only MAD-Ridge had a significantly greater density of fish larvae, particularly preflexion developmental stages, at the summit and slope (ON) stations relative to the deep sea control stations (DS), suggesting a seamount effect. This is in contrast to the findings of a comprehensive review by Boehlert and Mundy (1993), who found that the abundance of ichthyoplankton directly over seamounts is usually lower than in the surrounding oceanic waters. Even more-recent studies do not provide clear evidence of fish larvae retention at seamount summits (e.g. Genin and Dower, 2007), or the results are inconclusive owing to the limited number of samples (e.g. Hanel et al., 2010). It seems it is only at the Great Meteor Seamount (central North Atlantic) that a distinct ichthyoplankton 
community exists, and that there it is most likely linked to a strong retention potential around the seamount (Nellen and Ruseler, 2004; Diekmann et al., 2006).

In the present study, no clear evidence of a seamount effect, or a lack thereof, was found at either La Pérouse or Walters Shoal, although this could be due to limited sampling at those seamounts. To clarify this, more intensive studies are required that simultaneously examine vertical (discrete depths) and horizontal patterns of fish larvae, diel influences and physical parameters.

\subsection{Physical and environmental factors influencing fish larvae at seamounts}

The dominance of the TSW water mass at both MAD-Ridge and La Pérouse is reflected in the more diverse species composition of larval fish than at Walters Shoal, which lacked TSW. The most abundant myctophid larvae at La Pérouse and MAD-Ridge were $D$. brachycephalus, D. mollis, S. evermanni, L. luminosa and B.suborbitale, all with tropical and/or subtropical distributions (Olivar et al., 1999). Various studies have shown that larval stages of certain fish species are good indicators of water masses, such as mesopelagic myctophids that occur on shelf regions in the SWIO (Olivar and Beckley, 1994; Harris et al., 1999), North West Africa (Olivar et al., 2016), Western Australia (Holliday et al., 2012; Beckley et al., 2019), and South West Taiwan (Hsieh et al., 2017), but also clupeiformes off south Brazil (de Macedo-Soares et al., 2014), and Labridae and Stomiidae in the East Australian Current (Matis et al., 2014). Rogers et al. (2017) reported on the important influence of water mass types and major current systems on the pelagic communities of six seamounts distributed along the South West Indian Ridge, influencing the ecosystem more than the seamounts themselves. Our study also shows this.

As mentioned above, the neritic-associated taxa found at MAD-Ridge indicate a connection with the shelf waters of southern Madagascar. This connection is most likely 
451

452

453

454

455

456

457

458

459

460

461

462

463

464

465

466

467

468

469

470

471

472

473

474

475

476

attributable to cross-shelf transport of biological material from the Madagascar shelf, potentially feeding into the mesoscale eddy field offshore (Noyon et al., 2019; Vianello 2020b). The transport of fish larvae from nearby coastal waters by mesoscale features can have a major influence on the larval fish assemblages seamounts (e.g., Bonecker et al., 2006; Hanel et al., 2010). Mesoscale eddies retain plankton and larvae for some time, and because eddies are often more productive than surrounding waters, they can contribute to enhancing survival (Condie and Condie, 2016; Demarcq et al., 2020). Condie and Condie (2016) found that differences in retention capability with depth suggest that cyclonic and anticyclonic eddies will support different plankton communities. Results from our study support this statement too, because distinct groupings of fish larvae were evident in the different areas of the dipole eddy at MAD-Ridge. Other studies supporting the influence of mesoscale eddies in larval fish assemblage composition are in the Mediterranean (Cuttitta et al., 2016), Gulf of Alaska (Atwood et al., 2010), Australia (Holliday et al., 2011; Matis et al., 2014), southeast USA (Govoni et al., 2013) and the Canaries (Rodríguez et. al., 2004).

Another physical process hypothesised to explain aggregations of zooplankton and ichthyoplankton above seamounts is the Taylor column. This essentially is a stationary anticyclonic eddy formed above a shallow seamount that tends to trap plankton (Genin and Boehlert, 1985; Boehlert and Genin, 1987; Chapman and Haidvogel, 1992; Diekmann et al., 2006). However, evidence of Taylor columns in the field is sparse (Genin, 2004). Indeed Annasawmy et al. (2020) and Demarqc et al. (2020) both calculated that Taylor columns will probably not be found at the MAD-Ridge seamount, which was also supported by the field measurements of Vianello et al. (2020a).

Nonetheless, environmental variables that had some influence on the structuring of larval fish communities at La Pérouse and MAD-Ridge were mean temperature in the upper $200 \mathrm{~m}$ and DCM. At Walters Shoal, integrated Chl-a in the upper $200 \mathrm{~m}$ was also a factor, but with little of the total variation explained (see Table 5 - DistLM Best model $\mathrm{R}^{2}=0.28$ ). Certainly, 
478 is located, either physical processes (upwelling, mesoscale features, boundary currents) and/or environmental variables (temperature, salinity, turbidity, Chl-a) play a lesser or greater role in explaining variations in larval fish patterns. In this regard, mid-ocean, seamount, and continental slope regions have been observed often to be strongly influenced by water masses and boundary currents (e.g. Diekmann et. al., 2006; Hanel et. al., 2010; Holliday et. al., 2011; Matis et. al., 2014; Cuttitta et. al., 2016), and nearshore coastal regions by upwelling, river run-off and environmental variables (e.g. Laprise and Pepin, 1995; Harris et. al., 1999; Rodríguez et. al., 2015).

\subsection{Life history strategies and larval dispersal}

The origin and retention time of fish larvae at seamounts is a key question, because this affects local recruitment success. It is feasible that some young larvae of neritic reefassociated taxa found at MAD-Ridge originated from the southeast coast of Madagascar. A quick calculation shows that larvae transported in the SEMC at a mean speed of $0.79( \pm 0.21)$ $\mathrm{m} \mathrm{s}^{-1}$ (Ponsoni et al., 2016) would take approximately 3-5.7 days to reach the MAD-Ridge seamount (i.e. $86-45 \mathrm{~km} \mathrm{day}^{-1}$ ). The estimated ages of some of the young (preflexion) neriticreef associated taxa at MAD-Ridge were between 4 and 6 days; Diodontid sp.1, Cirrhitid sp.1 and Anthias sp.2 (Table 6), and therefore most likely not of seamount origin. In contrast, a few neritic-epipelagic species (Scomberomorus sp., Thunnus sp., R. laevis) were $<3$ days old, so are clearly spending their larval pelagic phase in the vicinity of this seamount. The same can be said for La Pérouse and Walters Shoal, where young larvae were present. Conclusions of seamount self-recruitment were similarly made by Dower and Perry (2001), who found great abundance of young rockfish (Sebastes spp.) larvae near Cobb Seamount, and by Hanel et. al. (2010), who found young larval stages of gobiids, scorpaenids and eels at the Senghor 
502

503

504

505

506

507

508

509

510

511

512

513

514

515

516

517

518

519

520

521

522

523

524

525

526

527

spawning by adult fish, the anticyclonic circulation of the eddy could have contributed to retaining newly hatched larvae on the seamount, thereby increasing the likelihood of local recruitment success. Such a situation was observed by Dooley (1984) where high recruitment of haddock larvae (Melanogrammus aeglefinus) on Rockall Bank took place in years when an anticyclonic eddy existed over the bank for a sufficiently long period to retain the larvae during their entire planktonic phase. However, although this is plausible, Crochelet et al. (2020) found that local retention at La Pérouse, MAD-Ridge and Walters Shoal was low, peaking at $10 \%$ for short pelagic larval duration (PLD) and decreasing with increasing PLD. However, to keep the modelling modest, those authors assumed passive larval dispersal, so their results may be an underestimation. Of course, it is well documented that late stage fish larvae are active swimmers and can modify their distribution patterns (Leis and CarsonEwart, 1997; Wolanski et al., 1997; Fischer et al., 2000). In fact, Faillettaz et al. (2018) suggested that fish larvae with strong directional swimming abilities would increase their likelihood of successful settlement, without being influenced by mesoscale oceanographic features.

PLD is species-dependent and can range from 9 to 93 days for reef fish communities (Stier et al., 2014). In our study for example, the acanthurid Naso sp. specimen collected at the MAD-Ridge seamount has a PLD of 84 days, Labrid spp. has a PDL of 26-28 days, Apogon spp. 18-34 days, and Synodus sp. 42 days (Stier et al., 2014). PLD can influence the scale of dispersion, with shorter ranges for larvae with short PLDs and greater distances with longer PLD (Hobbs et al., 2012). Crochelet et al. (2020) demonstrated great ichthyoplankton dispersal between the three seamounts and the coastal systems of the region (e.g. $1014 \mathrm{~km}$ with a PLD of 360 days for Walters Shoal).

\section{Concluding remarks}


529 coupling of ichthyoplankton assemblages around the Walters Shoal, MAD-Ridge and La

530 Pérouse seamounts. We established three null hypotheses. Our results indicate no significant

531 latitudinal gradient effect to explain the composition, abundance and spatial variability of

532 larval fish assemblages at the three seamounts. A seamount effect was not detected at either

533 La Pérouse or Walters Shoal. However, at the MAD-Ridge seamount, we did find a great

534 abundance of larvae at the summit stations relative to the offshore control stations.

535 Nonetheless, our analysis highlights the fact that other factors, such as oceanographic features

536 (mesoscale eddies), proximity to landmass and different water masses, all seem to have more

537 influence on the ichthyoplankton found at these seamounts in the SWIO. Finally, in support

538 of this, Kvile et. al. (2014) and Rowden et al. (2005) report that the varied morphologies,

539 depths at peak, base and elevation, and locations of seamounts, will consequently have very

540 different local environments and hence different faunal compositions.

\section{Appendix. Supplementary data}

542 Supplementary data to this article can be found online at https://doi.

$543 \quad$ org $/ 10.1016 / \mathrm{j} . \mathrm{dsr} 2.2020 \ldots \ldots$

\section{Acknowledgements}

We thank non-scientific and scientific staff for the collection of Bongo samples on board the R/V Antea for the oceanographic cruises at La Pérouse (DOI: 10.17600/16004500 and MAD-Ridge (DOI: 10.17600/16004800), and on board the R/V Marion Dufresne II for the

548 Walters Shoal expedition (MD 208, DOI: 10.17600/17002700). The study was mainly 549 supported with funding from the Institut de Recherche pour le Developpement (IRD) and the 550 International Centre for Education, Marine and Atmospheric Sciences over Africa 551 (ICEMASA). Additional funding was also received from Région Réunion (Réunion Regional 552 Council) for the La Pérouse cruise, from the Fonds Français pour l'Environnement Mondial 
554 of the South West Indian Ocean for the Walters Shoal expedition, and from the Newton Fund

555 (UK) and the National Research Foundation (NRF), South Africa.

\section{References}

Anderson M.J., Gorley R.N., Clarke K.R., 2008. PERMANOVA+ for PRIMER: Guide to Software and Statistical Methods. PRIMER-E: Plymouth, UK.

Annasawmy, P., Ternon, J-F., Lebourges-Dhaussy, A., Roudaut, G., Cotel, P., Herbette, S., Ménard, F., Marsac, F., 2020. Micronekton distribution as influenced by mesoscale eddies, Madagascar shelf and shallow seamounts in the south-western Indian Ocean: an acoustic approach. Deep-Sea Res. II (this issue)

Arkhipov, A.G., Mamedov, A.A., 2008. Ichthyoplankton of the Azores seamounts. J. Ichthyol. 48, 259-267.

Arkhipov, A. G., Sirota, A. A., Kozlov, D. A., 2004. Observations on hydrographic structures, ichthyoplankton and fish populations around seamounts of the centraleastern Atlantic. Arch. Fish. Mar. Res., 51, 177-190

Atwood, E., Diffy-Anderson, J., Horne, J.K., Ladd, C., 2010. Influence of mesoscale eddies on ichthyoplankton in the Gulf of Alaska. Fisheries Oceanography. 19, 493-507.

Beckley, L.E., Holliday, D., Sutton, A.L., Weller, E., Olivar, M-P., Thompson, P.A., 2019. Structuring of larval fish assemblages in the macro-tidal, tropical eastern Indian Ocean. Deep-Sea Res. II. 161, 105-119.

Belyanina, T. N., 1984. Observations on the ichthyofauna in the open waters of the Atlantic near the Great Meteor Seamount. J. Ichthyol. 24, 127-129.

Belyanina, T. N., 1993. An investigation of the ichthyoplankton on seamounts in the western Indian Ocean. J. Ichthyol. 33, 17-25.

Boehlert, G.W., 1988. Current-topography interactions at mid-ocean seamounts and the impact on pelagic ecosystems. GeoJournal. 16, 45-62.

Boehlert, G. W., Genin, A., 1987. A review of the effects of seamounts on biological processes. In Keating, B. H. E. A., Fryer, P., Batiza, R., Boehlert, G. W. et al. (eds), Seamounts, Islands, and Atolls. American Geophysical Union, Washington, D.C, pp. 319-334.

Boehlert, G.W., Mundy, B.C., 1993. Ichthyoplankton assemblages at seamounts and oceanic islands. Bull. Mar. Sci. 53, 336-361.

Bonecker, A.C.T., Castro, M.S., Namiki, C., Bonecker, F.T., Barros, F.B.A.G., MonteiroRibas, W.M., 2006. Ictioplâncton. In: Valentin, J.L. (Ed.) Características hidrobiológicas da região central da Zona Econômica Exclusiva brasileira (Salvador, BA, ao Cabo de São Tomé, RJ). Brasília: Ideal Gráfica e Editora. p.141-159 (Série Documentos REVIZEE/SCORE Central).

CBD, 2016. Ecologically or Biologically Significant Marine Areas (EBSAs). Special places in the world's oceans. Volume 3: Southern Indian Ocean. 128 pp.

Chapman, D.C., Haidvogel, D.B., 1992. Formation of Taylor caps over a tall isolated seamount in a stratified ocean. Geophysics and Astrophysics of Fluid Dynamics 64, $31-65$. 
Chelton, D.B., Schlax, M.G., Samelson, R.M., de Szoeke, R.A., 2007. Global observations of large oceanic eddies, Geophys. Res. Lett. 34, L15606, doi:10.1029/2007GL030812.

Clark, M.R., Schlacher, T.A, Rowden, A.A., Stocks, K.I, Consalvey, M., 2012. Science Priorities for seamounts: research links to conservation and management. PLoS ONE, 7(1): e29232. doi:10.1371/journal.pone.0029232.

Clarke, K.R., Gorley, R.N., 2015. PRIMER v7: User Manual/Tutorial (Plymouth Routines in Multivariate Ecological Research). PRIMER-E, Plymouth.

Collette, B.B, Parin, N.V., 1991. Shallow-water fishes of Walters Shoals, Madagascar Ridge. Bull. Mar. Sci. 48, 1-22.

Condie, S., Condie, R., 2016. Retention of plankton within ocean eddies. Global Ecol. Biogeogr. 25, 1264-1277.

Connell, A., 2012. Marine fish eggs and larvae from the east coast of South Africa. http://fisheggs-and-larvae.saiab.ac.za/

Crochelet, E., Barrier, N., Andrello, M., Marsac, F., Spadone, A., Lett, C., 2020. Connectivity between seamounts and coastal ecosystems in the Southwestern Indian Ocean. Deepsea Res. II (this issue)

Cuttitta, A., Quinci, E.M., Patti, B., Bonomo, S., Bonanno, A., Musco, M., Torri, M., Placenti, F., Basilone, G., Genovese, S., Armeri, G.M, Spanò,A., Arculeo, M., Mazzola, A., Mazzola, S., 2016. Different key roles of mesoscale oceanographic structures and ocean bathymetry in shaping larval fish distribution pattern: A case study in Sicilian waters in summer 2009. Journal of Sea Research 115, 6-17.

de Boyer-Montégut, C., Madec, G., Fischer, A.S., Lazar, I.A., Iudicone, D., 2004. Mixed layer depth over the global ocean: an examination of profile data and a profile-based climatology. J. Geophys. Res. 109, C12003, doi:10.1029/2004JC002378.

de Macedo-Soares, L.C.P.,, Garcia, C.A.E., Freire, A.S., Muelbert, J.H., 2014. Large-scale ichthyoplankton and water mass distribution along the South Brazil shelf. PLoS ONE 9(3): e91241. doi:10.1371/journal.pone.0091241

Demarcq, H., Noyon, M., Roberts, M.J. 2020. Phytoplankton enhancements depicted from ocean colour remote-sensing around seamounts: examples from the southwestern Indian Ocean. Deep-Sea Res. II (this issue).

de Ruijter, W.P.M., van Aken, H.M., Beierc, E.J., Lutjeharms, J.R.E., Matano, R.P., Schouten, M.W., 2004. Eddies and dipoles around South Madagascar: formation, pathways and large-scale impact. Deep-Sea Res. 51, 383-400.

Diekmann, R., Nellen, W., Piatkowski, U., 2006. A multivariate analysis of larval fish and paralarval cephalopod assemblages at Great Meteor Seamount. Deep-Sea Res. I 53, $1635-1657$.

Dooley, H.D., 1984. Aspects of oceanographic variability on Scottish fishing grounds. PhD thesis, University of Aberdeen.

Dower, J.F., MacKas, D.L., 1996. "Seamount effects" in the zooplankton community near Cobb Seamount. Deep-Sea Res. 43, 837-858.

Dower, J.F., Perry, R.I., 2001. High abundance of larval rockfish over Cobb Seamount, an isolated seamount in the Northeast Pacific. Fish. Oceanogr., 10, 268-274.

Faillettaz, R., Durand, E., Paris, C.B., Koubbi, P., Irisson, J-O., 2018. Swimming speeds of Mediterranean settlement-stage fish larvae nuance Hjort's aberrant drift hypothesis. Limnol. Oceanogr. 63, 509-523.

Fisher, R., Bellwood, D.R., Job, S.D., 2000. Development of swimming abilities in reef fish larvae. Mar. Ecol. Prog. Ser. 202, 163-173.

Garcia, S.M., Cohen, H., Freestone, D., Martinez, C., Oral, N., Rogers, A., Verlaan, P.A., Vousden, D., 2013. An Ecosystem Approach to Management of Seamounts in the Southern Indian Ocean. Volume 4 - A Road Map towards sustainable use and 
conservation of biodiversity in the Southern Indian Ocean. Gland, Switzerland: IUCN. $32+$ iv pp.

Genin, A., 2004. Bio-physical coupling in the formation of zooplankton and fish aggregations over abrupt topographies. J. Mar. Syst. 50, 3-20.

Genin, A., Boehlert, G.W., 1985. Dynamics of temperature and chlorophyll structures above a seamount: an oceanic experiment. J. Mar. Res. 43, 907- 924.

Genin, A., Dower, J.F., 2007. Seamount plankton dynamics, T.J. Pitcher, T. Morato, P.J.B. Hart, M.R. Clark, N. Haggan, Santos, R.S. (eds), in Seamounts: Ecology, Fisheries and Conservation, Fish and Aquatic Resources Series, Blackwell, Oxford, UK. pp. 85-100.

Gordina, A.D. 1991. Ichthyoplankton of the oceanic seamounts of the Atlantic and Indian oceans (Naukova Dumka, Kiev, 1991) [in Russian]

Govoni, J.J., Hare, J.A., Davenport, E.D., 2013. The distribution of larval fishes of the Charleston Gyre region off the Southeastern United States in winter shaped by mesoscale, cyclonic eddies, Mar. Coast. Fish., 5, 246-259. doi: $10.1080 / 19425120.2013 .820245$

Hanel, R., John, H-C., Klaeden, O., Piatkowski, U., 2010. Larval fish abundance, composition and distribution at Senghor Seamount (Cape Verde Islands). J. Plankt. Res. 32, 1541-1556.

Harris, S.A., Cyrus, D.P., Beckley, L.E., 1999. The larval fish assemblage in nearshore coastal waters off the St Lucia Estuary, South Africa. Estuar. Coast. Shelf Sci., 49, 789-811.

Hobbs, J-P.A., Jones, G.P., Munday, P.L, Connolly, S.R., Srinivasan, M., 2012. Biogeography and the structure of coral reef fish communities on isolated islands. J. Biogeogr., 39, 130-139.

Holliday, D., Beckley, L.E., Millar, N., Olivar, M-P., Slawinski, D., Feng, M., Thompson, P.A., 2012. Larval fish assemblages and particle back-tracking define latitudinal and cross-shelf variability in an eastern Indian Ocean boundary current. Mar. Ecol. Prog. Ser., 460, 127-144.

Holliday, D., Beckley, L.E., Olivar, M-P., 2011. Incorporation of larval fishes into a developing anti-cyclonic eddy of the Leeuwin Current off south-western Australia. J. Plankt. Res., 33, 1696-1708.

Hsieh, H-Y, Meng, P-J., Chang, Y-C., Lo, W-T., 2017. Temporal and spatial occurrence of mesopelagic fish larvae during epipelagic drift associated with hydrographic features in the Gaoping coastal waters off southwestern Taiwan. Mar. Coast. Fish., 9, 244-259, doi: 10.1080/19425120.2017.1293577.

Kvile, K.O., Taranto, G.H., Pitcher, T.J., Morato, T., 2014. A global assessment of seamount ecosystems knowledge using an ecosystem evaluation framework. Biol. Conserv., $173,108-120$.

Laprise, R., Pepin, P., 1995. Factors influencing the spatio-temporal occurrence of fish eggs and larvae in a northern, physically dynamic coastal environment. Mar. Ecol. Prog. Ser., 122, 73-92.

Leis, J.M. 1977. Development of the eggs and larvae of the slender Mola, Ranzaia laevis (Pisces, Molidae). Bull. Mar. Sci., 27, 448-466.

Leis, J.M., Carson-Ewart, B.M., 1997. In situ swimming speeds of the late pelagic larvae of some Indo-Pacific coral-reef fishes. Mar. Ecol. Prog. Ser., 159, 165-174.

Leis, J.M. and Carson-Ewart, B.M., 2000. The larvae of Indo-Pacific coastal fishes: an identification guide to marine fish larvae. Brill, $850 \mathrm{pp}$.

Leis, J.M., Caselle, J.E., Bradbury, I.R., Kristiansen, T., Llopiz, J.K., Miller, M.J, O’Connor, M.I., Paris, C.B., Shanks, A.L., Sogard, S.M., Swearer, S.E., Treml, E.A., Vetter, R.D., Warner, R.R., 2013. Does fish larval dispersal differ between high and low 
latitudes? Proc. R. Soc. http://dx.doi.org/10.1098/rspb.2013.0327

Makarim, S., Sprintall, J., Liu, Z., Yu, W., Santoso, A., Yan, X-H., Susanto, R.D., 2019. Previously unidentified Indonesian throughflow pathways and freshening in the Indian Ocean during recent decades. Scientific Reports. 9:7364, 1-13. https://doi.org/10.1038/s41598-019-43841-z

Marsac, F., Annasawmy, P., Noyon, M., Demercq, H., Soria, M., Rabearisoa, N., Bach, P., Cherel, Y., Grelet, J., Romanov, E., 2020. Seamount effect on circulation and distribution of ocean taxa in the vicinity of La Pérouse, a shallow seamount in the southwestern Indian Ocean. Deep-Sea Res. II (this issue).

Matis, P.A., Figueira, W.F., Suthers, I.M., Humphries, J., Miskiewicz, A., Coleman, R.A., Kelaher, B.P., Taylor, M.D., 2014. Cyclonic entrainment? The ichthyoplankton attributes of three major water mass types generated by the separation of the East Australian Current. ICES J. Mar. Sci., 71, 1696-1705.

Morato, T., Pitcher, T.J., Clark, M.R, Menezes, G., Tempera, F., Porteiro, F., Giacomello, E., Santos, R.S., 2010. Can we protect seamounts for research? A call for conservation. Oceanogr., 23, 190-199.

Moser, H.G. 1996. The early stages of fishes in the California Current region. CalCOFI Atlas 33. Allen Press Inc., Lawrence, 1505 pp.

Nellen, W., 1973. Investigations on the distribution of fish larvae and plankton near and above the Great Meteor Seamount. Meteo: Forsch Ergeb, 13, 47-69.

Nellen, W., Ruseler, S., 2004. Composition, horizontal and vertical distribution of ichthyoplankton in the Great Meteor Seamount area in September 1998. Arch. Fish. Mar. Res., 51, 132-164

Noyon • , · M., Morris • , T., Walker•, D., Huggett, J., 2019. Plankton distribution within a young cyclonic eddy off south-western Madagascar. Deep-Sea Res. II, 166, 141-150. https://doi.org/10.1016/j.dsr2.2018.11.001

Okiyama, M. (Ed.)., 1988. An atlas of the early stage fishes in Japan. Tokai Univ. Press, Tokyo. 1154 pp. [in Japanese].

Olivar, M-P., Beckley, L.E., 1994. Influence of the Agulhas Current on the distribution of lanternfish larvae off the south-east coast of Africa. J. Plankt. Res., 16, 1759-1780.

Olivar, M-P., Beckley, L.E., 1995. Early development of Diaphus spp. (Pisces: Myctophidae) of the Agulhas Current. S. Afr. J. mar. Sci., 16, 129-139.

Olivar, M-P., Beckley, L.E., 1997. Larval development of Lampanyctus species (Pisces: Myctophidae) from the SW Indian Ocean, and species groups based on larval characters. Bull. Mar. Sci., 60, 47-65.

Olivar, M-P., Moser, H.G., Beckley, L.E., 1999. Lanternfish larvae from the Agulhas Current (SW Indian Ocean). Scientia Mar., 63, 101-120.

Olivar, M-P., Sabatés, A., Pastor, M.V., Pelegrí, J.L., 2016. Water masses and mesoscale control on latitudinal and cross-shelf variations in larval fish assemblages off NW Africa. Deep-Sea Res. I, 117, 120-137.

Pollard, R., Read, J., 2017. Circulation, stratification and seamounts in the South West Indian Ocean. Deep-Sea Res. II, 136, 36-43

Ponsoni, L., Aguiar-González, B., Ridderinkhof, H., Maas, L.R.M., 2016. The East Madagascar Current: volume transport and variability based on long-term observations. J. Phys. Oceanogr., 46, 1045-1065.

Pous, S., Lazure, P., André, G., Dumas, F., Halo, I., Penven, P., 2014. Circulation around La Réunion and Mauritius islands in the south-western Indian Ocean: a modelling perspective. J. Geophys. Res. Oceans, 119, 1957-1976. 
Read, J., Pollard, R., 2017. An introduction to the physical oceanography of six seamounts in the south west Indian Ocean. Deep-Sea Res. II, 136, 44-58. http://dx.doi.org/10.1016/j.dsr2.2015.06.022i

Roberts, M.J., Ternon, J-F., Marsac, F., Noyon, M., 2020. The MADRidge Project: biophysical coupling around three shallow seamounts in the southwestern Indian Ocean. Deep-Sea Res. II (this issue).

Rodríguez, J.M., Barton, E.D., Hernández-León, S., Arístegui, J., 2004. The influence of mesoscale physical processes on the larval fish community in the Canaries CTZ, in summer. Prog. Oceanogr., 62, 171-188.

Rodríguez, J.M., Cabrero, A., Gago, J., Guevara-Fletcher, C., Herrero, M., Hernandez De Rojas, A., Garcia, A., Laiz-Carrion, R., Vergara, A.R., Alvarez, P., Neiro, C., Saborido-Rey, F., 2015. Vertical distribution and migration of fish larvae in the NW Iberian upwelling system during the winter mixing period: implications for cross-shelf distribution. Fish. Oceanogr., 24, 274-290.

Rogers, A.D., 2018. The biology of seamounts: 25 years on. Adv. Mar. Biol., 79, 137-224.

Rogers, A.D., Alvheim, O., Bemanaja, E., Benivary, D., 2017. Pelagic communities of the South West Indian Ocean seamounts: R/V Dr Fridtjof Nansen Cruise 2009-410. Deep-Sea Res. II, 136, 5-35.

Rowden, A.A., Clark, M.R., Wright, I.C. 2005. Physical characterisation and a biologically focused classification of 'seamounts' in the New Zealand region. NZ J. Mar. Freshw. Res., 39, 1039-1059.

Schlitzer, R. 2018. Ocean Data View, https://odv.awi.de

Shotton, R. 2006. Management of demersal fisheries resources of the southern Indian Ocean. Report of the fourth and fifth Ad Hoc Meetings on Potential Management Initiatives of Deepwater Fisheries Operators in the Southern Indian Ocean. FAO Fish. Circ., 1020.

Sigman, D.M., Hain, M.P., 2012. The biological productivity of the ocean. Nature Education, 3(6), $16 \mathrm{pp}$.

Smith, D.G., 1979. Guide to the Leptocephali (Elopiformes, Anguilliformes, and Notacanthiformes. NOAA Tech. Rep. NMFS Circ., 424.

Smith, M,M., Heemstra, P.C., 1986. Smiths' Sea Fishes. Macmillan South Africa, Johannesburg, $1047 \mathrm{pp}$.

Sobrinho-Gonçalves, L., Cardigos. F., 2006. Fish larvae around a seamount with shallow hydrothermal vents from the Azores. Thalassas, 22, 19-28.

Stier, A.C., Hein, A.M., Parravicini, V., Kulbicki, M., 2014. Larval dispersal drives trophic structure across Pacific coral reefs. Nature Comms, 5, 5575. doi: 10.1038/ncomms5575.

Stocco, L.B., and Joyeux, J-C., 2015. Distribution of fish larvae on the Vitória-Trindade Chain, southwestern Atlantic. Check List 11(2): 1590, doi: http://dx.doi.org/10.15560/11.2.1590.

Stocks, K.I., Clark, M.R, Rowden, A.A, Consalvey, M., Schlacher, T.A., 2012. CenSeam, an International program on seamounts within the Census of Marine Life: achievements and lessons learned. PLoS ONE, 7(2), e32031. doi:10.1371/ journal.pone.0032031.

Vianello, P., Ternon, J-F., Demarcq, H., Herbette, S., Roberts, M.J. 2020a. Ocean currents and environmental gradients of sea surface properties in the vicinity of the Madagascar Ridge in the southwestern Indian Ocean. Deep-Sea Res. II (this issue).

Vianello, P., Herbette, S., Ternon, J-F., Demarcq, H., Roberts, M.J. 2020b. Circulation and hydrography in the vicinity of a shallow seamount on the northern Madagascar Ridge. Deep-Sea Res. II (this issue).

Vinogradov, V.I., Arkhipov, A.G., Kozlov, D.A., 2014. Feeding of grey gurnard Eutrigla gurnardus (Triglidae) in the area of the Rockall Seamount. J. Ichthyol., 54, 243-248. 
Vousden, D., 2016. Productivity and biomass assessments for supporting management of the Agulhas Current and Somali Current Large Marine Ecosystems. Env. Dev., 17, 118125.

Wolanski, E., Doherty, P., Carleton, J., 1997. Directional swimming of fish larvae determines connectivity of fish populations on the Great Barrier Reef. Naturwissenchaften, 84, 262-268.

\section{Figure legends}

Fig. 1. (a) Location of the three seamounts La Pérouse, MAD-Ridge and Walters Shoal, in the Southwest Indian Ocean. Oceanographic mesoscale dynamics indicated by Mean Eddy Kinetic Energy (EKE), 1995-2015, with SRTM bathymetry overlay (Vianello et al., 2020a). Schematic ocean currents: AC, Agulhas Current; MCE, Mozambique Current Eddies; SEC, South Equatorial Current; NEMC, Northeast Madagascar Current; SEMC, Southeast Madagascar Current; EMRC, East Madagascar Return Current; SEME, South East Madagascar Eddies (Vousden, 2016). Shaded areas are Ecologically or Biologically Significant Marine Areas (EBSAs) (CBD, 2016). (b) Location of the sampling stations at each of the three seamounts La Pérouse, MAD-Ridge and Walters Shoal. Dots, ichthyoplankton stations; triangles, CTD stations.

Fig. 2. Ocean Data View (ODV) temperature-salinity plots of water masses in the upper 500 $\mathrm{m}$ at (a) La Pérouse, (b) MAD-Ridge, and (c) Walters Shoal seamounts: TSW, tropical surface water; STSW, subtropical surface water; SICW, South Indian Central Water, AAIW, Antarctic Intermediate Water (de Ruijter et al., 2004; Read and Pollard, 2017; Makarim et al., 2019). For MAD-Ridge, the anticyclonic eddy (AC) area with stations 22, 23 and 24 are indicated by the red circle.

Fig. 3. Sea Level Anomaly (SLA) showing the trajectory (black lines with dots) of the dipole eddy passing over the MAD-Ridge seamount between 29 October and 24 December 2016. West-East and North-South transects of the cruise measurements are indicated by black intersecting lines with the seamount location in the middle. White crosses indicate the position of the cyclone (C) and anticyclone (AC). Vianello et al. (2020b).

Fig. 4. Larval fish densities (larvae $100 \mathrm{~m}^{-3}$ ) at each station, for each seamount: (a) La Pérouse; (b) MAD-Ridge; (c) Walters Shoal. Stations OFF (DS, deep-sea >1500m) and ON (SU, summit < $350 \mathrm{~m}$ and SL, slope 350-1500 m) are indicated.

Fig. 5. (a) 3D Non-metric multidimensional scaling (nMDS) ordination of groupings of stations according to latitude. (b) nMDS of the six dominant species contributing to the groupings at each seamount. SIMPROF (slack 10\%) significant grouping for larval fish densities at all three seamount stations defined by latitude. T, tropical (La Pérouse); ST, subtropical (MAD-Ridge); ML, mid-latitude (Walters Shoal).

Fig. 6. Box plots for a) Total number of species (S), b) Shannon-Wiener diversity Index (H'), c) larval fish density (larvae $100 \mathrm{~m}^{-3}$, d) Preflexion (Pr), e) Flexion (Fl), f) Postflexion (Po) developmental stages, g) Oceanic Epipelagic, h) Oceanic Mesopelagic + Benthic, and i) Neritic Reef + Epipelagic + Benthic habitat association group, for OFF and ON seamount stations. OFF, deep-sea (DS) >1500 m; ON, Summit (SU) (<350 m) and slope (SL) (350- 
$8411500 \mathrm{~m}$. The lines in the box plots are: error bars $95 \%$ confidence interval; the bottom of the 842 box is the $25^{\text {th }}$ percentile; the top of the box is the 75 th percentile; the line inside the box is 843 the 50th percentile (median), and any outliers are shown as dots. LP, La Pérouse; MR, MAD844 Ridge; WS, Walters Shoal.

845 Fig. 7. Distance-based redundancy analysis (dbRDA) ordination, showing the structuring of 846 larval fish densities in relation to the six key environmental variables at each seamount with 847 latitude as a factor. T, Tropical (La Pérouse); ST, subtropical (MAD-Ridge); ML, mid848 latitude (Walters Shoal). T200, mean temperature within top $200 \mathrm{~m}$; DCM, deep chlorophyll 849 maximum; MLD, mixed layer depth.

850 Fig. 8. Canonical analysis of principal coordinates (CAP) for MAD-Ridge and the groupings 851 of fish larvae assemblages with eddy dipole as a factor. Cyclone, C; Anticylone, AC; 852 Transition anticyclone dipole, T-AC; Transition dipole zones, T-D. Vectors for species most 853 responsible for groupings are shown.

\section{Table Legends}

855 Table 1. Details of ichthyoplankton sampling at La Pérouse, MAD-Ridge and Walters Shoal 856 seamounts.

857 Table 2. Mean \pm standard deviation (and range) of environmental variables measured for each 858 seamount.

859 Table 3. Larval fish families, numbers, density (larvae $100 \mathrm{~m}^{-3}$ ), and percentage contribution 860 to the overall catch at each seamount, La Pérouse, MAD-Ridge and Walters Shoal.

861 Table 4. Summary of species identified by SIMPER (contributing $>3 \%$ to the nMDS pattern 862 in Fig. 5), Ave.Diss, average Bray-Curtis dissimilarity, Diss/SD, ratio of the average 863 contribution divided by the standard deviation (SD) of those contributions, Contrib\%, 864 contribution percentage.

865 Table 5. DistLM marginal tests using the $\mathrm{R}^{2}$ selection criteria, between larval fish 866 assemblages and six environmental variables selected based on Spearman Rank Correlation.

867 Table 6. Estimation of days old for selected species at each seamount. The value of $\mathrm{mm} / \mathrm{day}$ 868 is calculated from Connell (2012) grow-out work. 
Table 1. Details of ichthyoplankton sampling at La Pérouse, MAD-Ridge and Walters Shoal seamounts.

\begin{tabular}{|c|c|c|c|}
\hline & La Pérouse & MAD-Ridge & Walters Shoal \\
\hline Total number of stations & 9 & 19 & 9 \\
\hline $\begin{array}{l}\text { Control stations }(>10 \mathrm{M} \\
\text { outside the seamount) }\end{array}$ & $\begin{array}{l}8 \text { (West), } 10 \text { (East), } 2 \\
\quad(\text { South), } 1 \text { (North) }\end{array}$ & $\begin{array}{l}\text { 2, 4, } 6 \text { (West), 10, 12, } 14 \text { (East), 16, } \\
\text { 18, } 19 \text { (South), 24, 25, } 27 \text { (North) }\end{array}$ & none \\
\hline Seamount stations & $4,6,9,23,24$ & $7,8,9,20,21,22,23$ & $5,7,8,9,11,12,13,14,15$ \\
\hline Depth sampled (m) & $500 \mathrm{~m}$ at all stations & $\begin{array}{l}500 \mathrm{~m} \text { at all stations except the } \\
\text { shallower stations }(8,21,22) \text {, where } \\
\text { the oblique tows were from as close to } \\
\text { the bottom as possible }\end{array}$ & $\begin{array}{c}500 \mathrm{~m} \text { at all stations except the } \\
\text { shallower stations }(9,11,15) \text { where } \\
\text { the oblique tows were from a depth } \\
\text { of } 200 \mathrm{~m}\end{array}$ \\
\hline $\begin{array}{l}\text { Average }( \pm \mathrm{SE}) \text { seawater } \\
\text { sampled from Bongo net } \\
\text { samples }\left(100 \mathrm{~m}^{-3}\right)\end{array}$ & $1059.66(279.86)$ & $691.45(254.25)$ & $1445.27(435.39)$ \\
\hline Day/night & Daytime & $\begin{array}{l}\text { Daytime, except station } 18 \text {, which was } \\
\text { sampled in the early evening }\end{array}$ & Daytime \\
\hline
\end{tabular}


Table 2. Mean \pm standard deviation (and range) of environmental variables measured for each seamount.

\begin{tabular}{lccc}
\hline & La Pérouse & MAD-Ridge & Walters Shoal \\
\hline Bottom depth (m) & $1936 \pm 1322(550-4203)$ & $1276 \pm 645(255-1964)$ & $545 \pm 162(321-704)$ \\
Mixed layer depth (MLD) (m) & $62 \pm 22(34-106)$ & $58 \pm 24(21-100)$ & $37 \pm 11(24-63)$ \\
Deep Chlorophyll Maximum (DCM) (m) & $107 \pm 30(54-196)$ & $116 \pm 30(54-196)$ & $38 \pm 9(22-52)$ \\
Mean Temperature upper 200m (T200) $\left({ }^{\circ} \mathrm{C}\right)$ & $21.94 \pm 0.17(22.19-21.09)$ & $22.66 \pm 0.90(19.55-23.44)$ & $18.21 \pm 0.37(17.54-18.69)$ \\
Mean Salinity upper 200 m (S200) $\left(\mathrm{g} \mathrm{kg}^{-1}\right)$ & $35.31 \pm 0.03(35.26-35.35)$ & $35.32 \pm 0.05(35.26-35.46)$ & $35.56 \pm 0.01(35.54-35.57)$ \\
Integrated Chl-a 200m $\left(\mathrm{mg} \mathrm{m}^{-3}\right)^{*}$ & $30.73 \pm 3.26(26.43-35.80)$ & $31.58 \pm 5.15(25.34-48.60)$ & $62.05 \pm 13.37(44.12-82.54)$ \\
Zooplankton settled volume $\left(\mathrm{ml} \mathrm{m}^{-3}\right)$ & $0.028 \pm 0.015(0.007-0.053)$ & $0.056 \pm 0.021(0.032-0.119)$ & $0.026 \pm 0.015(0.008-0.054)$ \\
\hline
\end{tabular}

* Sum of Chl-a in the upper $200 \mathrm{~m}$ 
Table 3. Larval fish families, numbers, density (larvae $100 \mathrm{~m}^{-3}$ ), and $\%$ contribution to the overall catch at each seamount, La Pérouse, MAD-Ridge and Walters Shoal.

\begin{tabular}{|c|c|c|c|c|c|c|c|c|c|c|c|}
\hline \multirow[b]{2}{*}{ Family } & & & \multicolumn{3}{|c|}{ La Pérouse } & \multicolumn{3}{|c|}{ MAD-Ridge } & \multicolumn{3}{|c|}{ Walters Shoal } \\
\hline & \multicolumn{2}{|c|}{ Habitat Association } & No. & larvae $100 \mathrm{~m}^{-3}$ & $\%$ & No. & larvae $100 \mathrm{~m}^{-3}$ & $\%$ & No. & larvae $100 \mathrm{~m}^{-3}$ & $\%$ \\
\hline Acanthuridae & neritic & reef & & & & 2 & 0.350 & 0.24 & & & \\
\hline Acropomatidae & oceanic & mesopelagic & 4 & 0.545 & 1.81 & 8 & 1.096 & 0.75 & & & \\
\hline Ammodytidae & neritic & benthic & & & & 4 & 0.722 & 0.49 & & & \\
\hline Anguilliformes & neritic & reef & & & & 6 & 1.035 & 0.71 & & & \\
\hline Apogonidae & neritic & reef & & & & 2 & 0.315 & 0.21 & & & \\
\hline Astronesthidae & oceanic & mesopelagic & 2 & 0.169 & 0.56 & 5 & 0.677 & 0.47 & & & \\
\hline Aulopiformes & oceanic & mesopelagic & 2 & 0.264 & 0.88 & & 0.677 & & & & \\
\hline Bathylagidae & oceanic & mesopelagic & & & & 1 & 0.189 & 0.13 & & & \\
\hline Blenniidae & neritic & reef & 1 & 0.088 & 0.29 & & & & & & \\
\hline Bothidae & neritic & benthic & & & & 4 & 0.407 & 0.28 & & & \\
\hline Bramidae & neritic & epipelagic & & & & 4 & 0.604 & 0.41 & & & \\
\hline Bregmacerotidae & neritic & epipelagic & 7 & 0.604 & 2.00 & 87 & 11.849 & 8.07 & & & \\
\hline Bythitidae & neritic & reef & & & & 2 & 0.310 & 0.21 & & & \\
\hline Callionymidae & neritic & reef & & & & 3 & 0.735 & 0.50 & & & \\
\hline Carangidae & neritic & epipelagic & & & & 3 & 0.466 & 0.32 & & & \\
\hline Carapidae & oceanic & benthopelagic & 1 & 0.074 & 0.25 & 1 & 0.155 & 0.11 & & & \\
\hline Caristiidae & oceanic & mesopelagic & 1 & 0.074 & 0.25 & & & & & & \\
\hline Chamsodontidae & oceanic & mesopelagic & & & & 2 & 0.157 & 0.11 & & & \\
\hline Chauliodontidae & oceanic & mesopelagic & & & & 3 & 0.517 & 0.35 & & & \\
\hline Cirrhitidae & neritic & reef & & & & 3 & 0.451 & 0.31 & & & \\
\hline Coryphaenidae & oceanic & epipelagic & & & & 5 & 0.582 & 0.40 & & & \\
\hline Derichthyidae & oceanic & mesopelagic & & & & 1 & 0.171 & 0.12 & & & \\
\hline Diodontidae & neritic & reef & & & & 1 & 0.189 & 0.13 & & & \\
\hline Diretmidae & oceanic & mesopelagic & 1 & 0.075 & 0.25 & & & & & & \\
\hline
\end{tabular}




\begin{tabular}{|c|c|c|c|c|c|c|c|c|c|c|c|}
\hline Evermannellidae & oceanic & mesopelagic & & & & 4 & 0.614 & 0.42 & & & \\
\hline Exocoetidae & oceanic & epipelagic & & & & 1 & 0.117 & 0.08 & & & \\
\hline Gempylidae & oceanic & benthopelagic & 1 & 0.088 & 0.29 & 3 & 0.637 & 0.43 & & & \\
\hline Gobiidae & neritic & reef & & & & 7 & 1.145 & 0.78 & & & \\
\hline Gonostomatidae & oceanic & mesopelagic & 75 & 7.854 & 26.07 & 82 & 13.065 & 8.70 & 50 & 3.461 & 37.84 \\
\hline Hemiramphidae & neritic & epipelagic & & & & 1 & 0.146 & 0.10 & & & \\
\hline Idiacanthidae & oceanic & mesopelagic & & & & 7 & 0.997 & 0.68 & 3 & 0.252 & 2.79 \\
\hline Labridae & neritic & reef & 1 & 0.176 & 0.58 & 8 & 1.219 & 0.83 & & & \\
\hline Lutjanidae & neritic & reef & & & & 1 & 0.189 & 0.13 & & & \\
\hline Macrouridae & oceanic & mesopelagic & 1 & 0.132 & 0.44 & 2 & 0.377 & 0.26 & & & \\
\hline Melamphaidae & oceanic & mesopelagic & & & & 4 & 0.588 & 0.40 & 15 & 1.026 & 11.38 \\
\hline Melanocetidae & oceanic & mesopelagic & & & & 1 & 0.236 & 0.16 & 1 & 0.140 & 1.56 \\
\hline Melanostomiidae & oceanic & mesopelagic & 2 & 0.159 & 0.53 & 4 & 0.595 & 0.41 & & & \\
\hline Molidae & oceanic & epipelagic & & & & 109 & 18.588 & 12.66 & & & \\
\hline Mullidae & neritic & reef & & & & 5 & 0.634 & 0.43 & & & \\
\hline Muraenidae & neritic & reef & 1 & 0.074 & 0.25 & & & & & & \\
\hline Myctophidae & oceanic & mesopelagic & 128 & 14.118 & 46.85 & 402 & 68.913 & 46.94 & 38 & 3.215 & 35.67 \\
\hline Nemichthyidae & oceanic & mesopelagic & 1 & 0.125 & 0.41 & 1 & 0.122 & 0.08 & & & \\
\hline Nomeidae & oceanic & epipelagic & & & & 16 & 2.991 & 2.04 & & & \\
\hline Notosudidae & oceanic & mesopelagic & 10 & 0.833 & 2.76 & 2 & 0.301 & 0.21 & 4 & 0.294 & 3.27 \\
\hline Ogcocephalidae & oceanic & mesopelagic & & & & 1 & 0.255 & 0.17 & & & \\
\hline Ophidiidae & oceanic & mesopelagic & & & & 3 & 0.236 & 0.16 & & & \\
\hline Paralepididae & oceanic & mesopelagic & 7 & 0.818 & 2.72 & 12 & 2.246 & 1.53 & & & \\
\hline Pempheridae & neritic & reef & & & & 1 & 0.193 & 0.13 & & & \\
\hline Perciformes & neritic & reef & & & & 3 & 0.500 & 0.34 & & & \\
\hline Percophidae & oceanic & benthopelagic & & & & 3 & 0.532 & 0.36 & & & \\
\hline Phosichthyidae & oceanic & mesopelagic & 18 & 2.428 & 8.06 & 15 & 2.224 & 1.52 & 1 & 0.051 & 0.57 \\
\hline Pomacanthidae & neritic & reef & 1 & 0.125 & 0.41 & 2 & 0.267 & 0.18 & & & \\
\hline Priacanthidae & neritic & reef & & & & 1 & 0.171 & 0.12 & & & \\
\hline Samaridae & neritic & benthic & & & & 1 & 0.074 & 0.05 & & & \\
\hline Scaridae & neritic & reef & 1 & 0.075 & 0.25 & 3 & 0.576 & 0.39 & & & \\
\hline Scombridae & oceanic & epipelagic & & & & 15 & 2.046 & 1.39 & & & \\
\hline Scopelarchiidae & oceanic & mesopelagic & 4 & 0.334 & 1.11 & 6 & 0.885 & 0.60 & & & \\
\hline Scorpaenidae & neritic & reef & & & & 1 & 0.122 & 0.08 & & & \\
\hline
\end{tabular}




\begin{tabular}{|c|c|c|c|c|c|c|c|c|c|c|c|}
\hline Serranidae & neritic & reef & & & & 4 & 0.681 & 0.46 & & & \\
\hline Sphyraenidae & oceanic & epipelagic & & & & 3 & 0.729 & 0.50 & 1 & 0.096 & 1.07 \\
\hline Sternoptychidae & oceanic & mesopelagic & 7 & 0.899 & 2.98 & 17 & 2.091 & 1.42 & 7 & 0.527 & 5.85 \\
\hline Synodontidae & neritic & benthic & & & & 3 & 0.389 & 0.26 & & & \\
\hline Tetraodontidae & neritic & reef & & & & 1 & 0.079 & 0.05 & & & \\
\hline Trichiuridae & oceanic & benthopelagic & & & & 2 & 0.364 & 0.25 & & & \\
\hline Unidentified & & & 22 & 0.984 & & 60 & 9.869 & & 9 & 0.535 & \\
\hline \multicolumn{3}{|l|}{ Grand Total } & 299 & 31.114 & & 964 & 156.980 & & 129 & 9.598 & \\
\hline \multicolumn{3}{|l|}{ Total No. families } & 23 & & & 58 & & & 9 & & \\
\hline \multicolumn{3}{|c|}{ Total No. species/taxa } & 54 & & & 127 & & & 24 & & \\
\hline
\end{tabular}


Table 4. Summary of species identified by SIMPER (contributing $>3 \%$ to the nMDS pattern in Fig. 5), Ave.Diss, average Bray-Curtis dissimilarity,

Diss/SD, ratio of the average contribution divided by the standard deviation (SD) of those contributions, Contrib\%, contribution percentage.

\section{LP MR WS}

LP vs MR

ave density
$\left(\right.$ no.100 $\left.\mathrm{m}^{-3}\right)$

Ranzania laevis

Myctophid unidents

Cyclothone alba

$0.220 . \overline{6} 2$

$0.82 \quad 0.54$

Cyclothone pseudopallida

Hygophum proximum

Melamphaes sp.1

Myctophid sp.1

Bregmaceros

Vinciguerria lucetia

Argyropelecus sladeni

AVE Dissimilarity

4.23

1.13

0.69

0.59

0.42

0.22

0.08

0.39

$0.38 \quad 0.20$

$0.29 \quad 0.16$

84.86
LP vs WS

MR vs WS

\begin{tabular}{lllllll}
\hline Ave.Diss & Diss/SD & Contrib\% & Ave.Diss Diss/SD & Contrib\% & Ave.Diss & Diss/SD Contrib\%
\end{tabular}

$\begin{array}{lll}6.08 & 1.38 & 7.16\end{array}$

$\begin{array}{lll}5.30 & 0.85 & 6.25\end{array}$

6.25

$\begin{array}{lll}3.26 & 0.87 & 3.84 \\ 2.95 & \bigcirc .96 & 3.48\end{array}$

.16

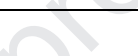

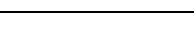

(2)

7.18

5.97

1.39

0.78

7.60

\subsection{1}

2.23

8.30

4.61

1.05

6.32

6.80

1.45

7.13

6.01

1.55

4.88

6.42

1.29

6.74

5.14

1.32

6.36

4.57

0.86

4.80

3.91

0.97

5.44

3.28

0.61

3.44

3.23

0.85

3.84

0.88

4.06

2.89

0.92

3.38

93.35

0.91

3.04 
Table 5. DistLM marginal tests using the $\mathbf{R}^{2}$ selection criteria, between larval fish assemblages and six environmental variables selected based on Spearman Rank Correlation.

\begin{tabular}{lcccc} 
Variable & SS & Pseudo-F & p & \% explained \\
\hline Bottom depth $(\mathrm{m})$ & 6084 & 1.664 & 0.499 & $4.5 \%$ \\
MLD $(\mathrm{m})$ & 5242 & 1.424 & 0.130 & $3.9 \%$ \\
DCM $(\mathrm{m})$ & 19497 & 5.597 & $0.001^{*}$ & $14.6 \%$ \\
Mean temp. above 200 m $(\mathrm{T} 200)$ & 2283 & 7.204 & $0.001^{*}$ & $17.0 \%$ \\
Integrated Chla-a 200 $\left.\mathrm{mg} \mathrm{m}^{-3}\right)$ & 19050 & 5.798 & $0.001^{*}$ & $14.2 \%$ \\
Zooplankton settled volume $\left(\mathrm{ml} \mathrm{m}^{-3}\right)$ & 8772 & 2.450 & $0.009^{*}$ & $6.5 \%$ \\
Best model $\mathbf{R}^{\mathbf{2}}=\mathbf{0 . 2 8}($ all variables) & & & &
\end{tabular}

* Significant $(\mathrm{p}<0.05)$ 


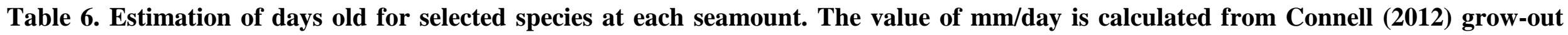
907 work.

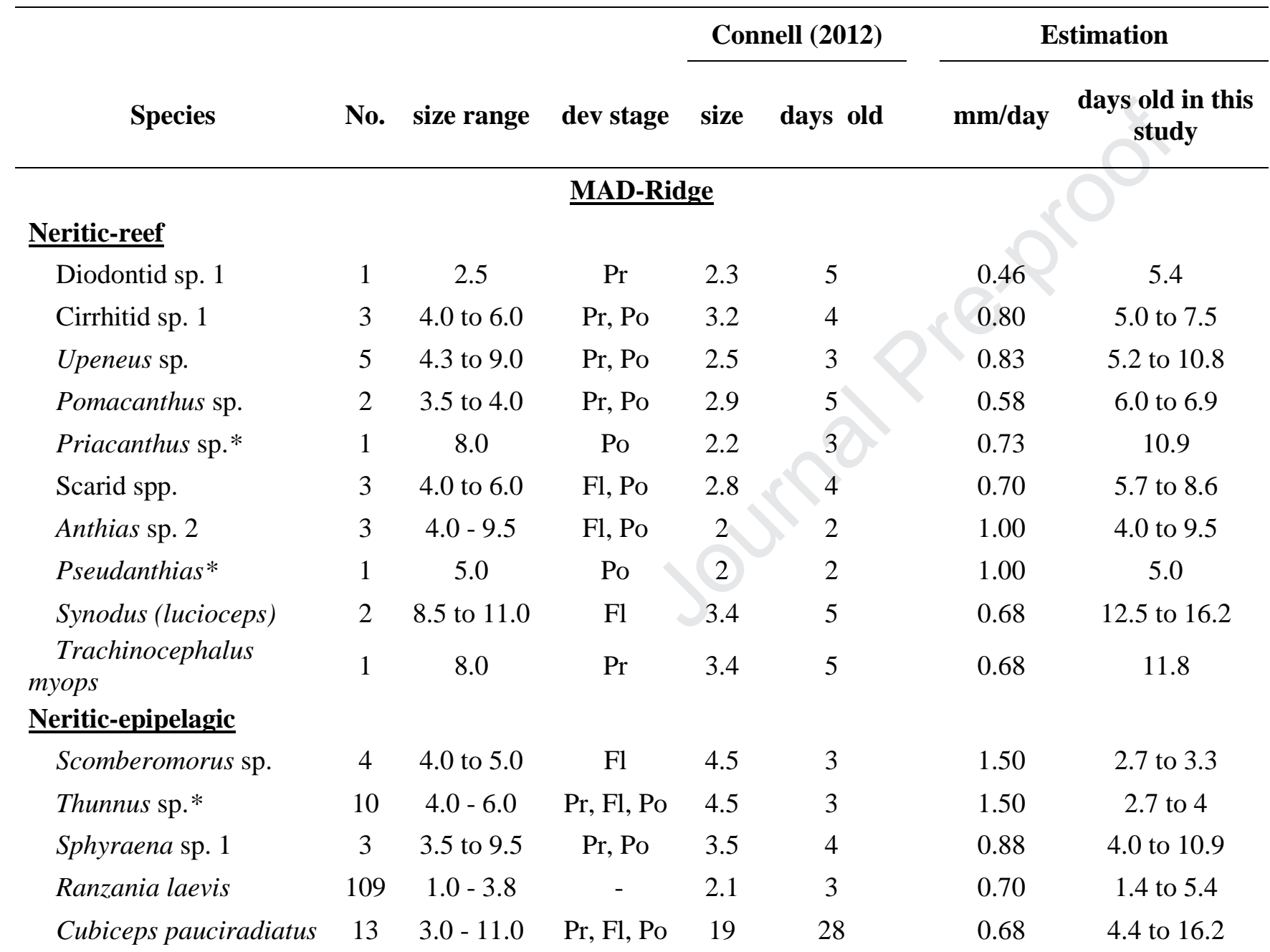




\section{La Pérouse}

\section{Neritic-reef}

Pomacanthid sp.

$1 \quad 4.2 \quad$ Pr 2.9

Scarus sp.

$1 \quad 4.8$

Po

2.8

0.58

7.2

Oceanic-mesopelagic

Macrourid sp.

$1 \quad 1.5$

Pr $\quad 3.8$

0.70

6.9

Vinciguerria spp.

$18 \quad 4.0$ to $16.0 \quad \mathrm{Pr}, \mathrm{Fl}, \mathrm{Po} \quad 3$

Walters Shoal

\begin{tabular}{ccccccccc} 
Sphyraena sp. & 1 & 3.0 & Pr & 3.5 & 4 & 0.88 & 3.4 \\
\hline * Used another species in the family as an estimate (Connell, 2012) & &
\end{tabular}


Appendix A. Summary of families and species, density (larvae $100 \mathrm{~m}^{-3}$ ), minimum, maximum and average size, and developmental stages recorded at the La Pérouse seamount.

\begin{tabular}{|c|c|c|c|c|c|c|c|}
\hline & \multirow[b]{2}{*}{$\begin{array}{c}\text { Overall } \\
\text { rank }\end{array}$} & \multirow[b]{2}{*}{ No. } & \multirow[b]{2}{*}{ larvae $100 \mathrm{~m}^{-3}$} & \multicolumn{3}{|c|}{ Size $(\mathbf{m m})$} & \multirow[b]{2}{*}{$\begin{array}{c}\text { Dev } \\
\text { stages }\end{array}$} \\
\hline & & & & Min & Max & Ave & \\
\hline \multicolumn{8}{|l|}{ Acropomatidae } \\
\hline Howella sp. & 10 & 5 & 0.621 & 3.0 & 5.0 & 3.3 & Pr, Po \\
\hline \multicolumn{8}{|l|}{ Astronestidae } \\
\hline Astronestid sp. 2 & & 1 & 0.084 & 10.0 & 10.0 & 10.0 & $\mathrm{Fl}$ \\
\hline Astronestid sp. 3 & & 1 & 0.084 & 8.0 & 8.0 & 8.0 & $\mathrm{Fl}$ \\
\hline \multicolumn{8}{|l|}{ Aulopiformes } \\
\hline Aulopiform sp. & & 2 & 0.264 & 5.5 & 6.0 & 5.8 & $\mathrm{Pr}, \mathrm{Fl}$ \\
\hline \multicolumn{8}{|l|}{ Bregmacerotidae } \\
\hline Bregmaceros sp. & & 7 & 0.604 & 2.0 & 3.0 & 2.5 & $\operatorname{Pr}$ \\
\hline \multicolumn{8}{|l|}{ Carapidae } \\
\hline Encheliophis sp. & & 1 & 0.074 & 36.0 & 36.0 & 36.0 & $\operatorname{Pr}$ \\
\hline \multicolumn{8}{|l|}{ Caristiidae } \\
\hline Caristiid sp. & & 1 & 0.074 & 3.0 & 3.0 & 3.0 & $\operatorname{Pr}$ \\
\hline \multicolumn{8}{|l|}{ Coryphaenidae } \\
\hline Coryphaena hippurus & & 1 & 0.088 & 12.0 & 12.0 & 12.0 & Po \\
\hline \multicolumn{8}{|l|}{ Diretmidae } \\
\hline Diretmid sp. & & 1 & 0.075 & 5.0 & 5.0 & 5.0 & $\operatorname{Pr}$ \\
\hline \multicolumn{8}{|l|}{ Gempylidae } \\
\hline Gempylid sp. 1 & & 1 & 0.088 & 65.0 & 65.0 & 65.0 & Po \\
\hline \multicolumn{8}{|l|}{ Gonostomatidae } \\
\hline Cyclothone alba & 1 & 65 & 6.882 & 4.0 & 18.0 & 9.1 & $\mathrm{Pr}, \mathrm{Fl}, \mathrm{Po}$ \\
\hline Gonostoma elongatum & & 4 & 0.449 & 6.5 & 8.0 & 7.4 & Po \\
\hline Gonostoma sp. & & 6 & 0.523 & 4.5 & 8.0 & 5.7 & Fl, Po \\
\hline \multicolumn{8}{|l|}{ Labridae } \\
\hline Labrid sp. 15 & & 1 & 0.176 & 15.0 & 15.0 & 15.0 & Po \\
\hline \multicolumn{8}{|l|}{ Macrouridae } \\
\hline Macrourid sp. & & 1 & 0.132 & 1.5 & 1.5 & 1.5 & $\operatorname{Pr}$ \\
\hline \multicolumn{8}{|l|}{ Melanostomiidae } \\
\hline Tactostoma sp.? & & 2 & 0.159 & 7.0 & 30.0 & 18.5 & Fl, Po \\
\hline \multicolumn{8}{|l|}{ Muraenidae } \\
\hline Muraenid sp. 1 & & 1 & 0.074 & 58.0 & 58.0 & 58.0 & Le \\
\hline \multicolumn{8}{|l|}{ Myctophidae } \\
\hline Benthosema pterotum & & 3 & 0.375 & 4.5 & 5.8 & 5.1 & Po \\
\hline Benthosema suborbitale & & 2 & 0.175 & 3.0 & 3.8 & 3.4 & $\operatorname{Pr}$ \\
\hline Benthosema sp. 1 & & 3 & 0.375 & 4.5 & 5.5 & 4.8 & Po \\
\hline Bolinichthys sp. & & 1 & 0.088 & 13.0 & 13.0 & 13.0 & Po \\
\hline Centroscopelus sp. & 7 & 8 & 0.701 & 4.0 & 6.5 & 4.8 & Pr, Po \\
\hline Diaphus brachycephalus & 8 & 3 & 0.653 & 5.0 & 8.0 & 6.0 & Po \\
\hline Diaphus sp. 1 & & 2 & 0.352 & 4.5 & 5.0 & 4.8 & $\mathrm{Fl}, \mathrm{Po}$ \\
\hline
\end{tabular}




\begin{tabular}{|c|c|c|c|c|c|c|c|}
\hline Diaphus sp. 2 & $5^{\circ}$ & 5 & ${ }^{0} 1.000$ & 4.5 & 6.5 & 5.1 & Po \\
\hline Diaphus sp. 3 & 6 & 10 & 0.845 & 3.0 & 5.5 & 4.1 & Pr, Fl, Po \\
\hline Diaphus theta & & 5 & 0.408 & 6.0 & 7.0 & 6.5 & Po \\
\hline Diogenichthys sp. & & 1 & 0.264 & 5.5 & 5.5 & 5.5 & $\mathrm{Fl}$ \\
\hline Hygophum sp. 1 & 9 & 5 & 0.639 & 4.0 & 5.0 & 4.2 & $\mathrm{Pr}, \mathrm{Fl}$ \\
\hline Lampanyctus sp. 1 & & 3 & 0.410 & 3.0 & 4.0 & 3.5 & $\operatorname{Pr}$ \\
\hline Lampanyctus sp. 2 & & 2 & 0.175 & 4.0 & 4.5 & 4.3 & $\operatorname{Pr}$ \\
\hline Lampanyctus sp. 3 & & 3 & 0.351 & 4.0 & 5.0 & 4.6 & $\mathrm{Fl}$ \\
\hline Lobianchia gemellani & & 1 & 0.125 & 3.8 & 3.8 & 3.8 & $\mathrm{Fl}$ \\
\hline Lobianchia sp. 1 & & 1 & 0.264 & 4.0 & 4.0 & 4.0 & $\mathrm{Fl}$ \\
\hline Myctophum brachygnathum & & 1 & 0.088 & 6.0 & 6.0 & 6.0 & Po \\
\hline Myctophum nitidulum & & 6 & 0.565 & 3.0 & 5.5 & 4.1 & $\mathrm{Pr}, \mathrm{Fl}$ \\
\hline Protomyctophum? & & 1 & 0.176 & 8.0 & 8.0 & 8.0 & $\mathrm{Fl}$ \\
\hline Symbolophorus evermanni & 4 & 9 & 1.149 & 3.0 & 8.0 & 5.0 & $\mathrm{Pr}, \mathrm{Fl}, \mathrm{Po}$ \\
\hline Taaningichthys sp. & & 1 & 0.074 & 5.5 & 5.5 & 5.5 & $\operatorname{Pr}$ \\
\hline Myctophid unidents & 2 & 50 & 3.715 & 3.0 & 7.0 & 4.6 & Pr, Fl, Po \\
\hline \multicolumn{8}{|l|}{ Nemichthyidae } \\
\hline Avocettina sp. & & 1 & 0.125 & 8.0 & 8.0 & 8.0 & Le \\
\hline \multicolumn{8}{|l|}{ Notosudidae } \\
\hline Notosudid sp.1 & & 4 & 0.310 & 11.0 & 15.0 & 12.3 & $\mathrm{Fl}, \mathrm{Po}$ \\
\hline Scopelarchus sp. & & 6 & 0.523 & 5.0 & 8.0 & 6.3 & $\operatorname{Pr}$ \\
\hline \multicolumn{8}{|l|}{ Paralepididae } \\
\hline Lestidiops sp. 1 & & 3 & 0.222 & 6.5 & 7.0 & 6.7 & $\operatorname{Pr}$ \\
\hline Lestidiops sp. 2 & & 1 & 0.264 & 8.0 & 8.0 & 8.0 & $\operatorname{Pr}$ \\
\hline Paralepid sp. 1 & & 2 & 0.257 & 5.5 & 9.0 & 7.3 & $\mathrm{Pr}, \mathrm{Po}$ \\
\hline Sudis atrox & & 1 & 0.075 & 9.5 & 9.5 & 9.5 & Po \\
\hline \multicolumn{8}{|l|}{ Phosichthyidae } \\
\hline Vinciguerria lucetia & & 18 & 2.428 & 4.0 & 16.0 & 8.5 & $\mathrm{Pr}, \mathrm{Fl}, \mathrm{Po}$ \\
\hline \multicolumn{8}{|l|}{ Pomacanthidae } \\
\hline Pomacanthid sp. 1 & & 1 & 0.125 & 4.2 & 4.2 & 4.2 & $\operatorname{Pr}$ \\
\hline \multicolumn{8}{|l|}{ Scaridae } \\
\hline Scarus sp. & & 1 & 0.075 & 4.8 & 4.8 & 4.8 & Po \\
\hline \multicolumn{8}{|l|}{ Scopelarchidae } \\
\hline Benthalbella sp. & & 3 & 0.249 & 9.5 & 18.0 & 12.8 & Po \\
\hline Scopelarchus guentheri & & 1 & 0.084 & 21.0 & 21.0 & 21.0 & Po \\
\hline \multicolumn{8}{|l|}{ Sternoptychidae } \\
\hline Argyropelecus lychnus & & 3 & 0.528 & 6.5 & 8.0 & 7.2 & Pr, Po \\
\hline Argyropelecus sladeni & & 4 & 0.371 & 7.0 & 9.0 & 7.6 & $\mathrm{Fl}, \mathrm{Po}$ \\
\hline Unidentified & & 46 & 3.756 & 1.5 & 8.0 & 4.0 & Pr, Fl, Po \\
\hline Grand Total & & 299 & 31.114 & & & & \\
\hline Total no. families & & 23 & & & & & \\
\hline Total no. species/taxa & & 54 & & & & & \\
\hline
\end{tabular}


Appendix B. Summary of families and species, density (larvae $100 \mathrm{~m}^{-3}$ ), minimum, maximum and average size, and developmental stages recorded at the MAD-Ridge seamount.

\begin{tabular}{|c|c|c|c|c|c|c|c|}
\hline & \multirow[b]{2}{*}{$\begin{array}{c}\text { Overall } \\
\text { rank }\end{array}$} & \multirow[b]{2}{*}{ No. } & \multicolumn{5}{|c|}{ Size (mm) } \\
\hline & & & larvae $100 \mathrm{~m}^{-3}$ & Min & Max & Ave & Dev stages \\
\hline \multicolumn{8}{|l|}{ Acanthuridae } \\
\hline Acanthurid sp. 2 & & 1 & 0.180 & 4.0 & 4.0 & 4.0 & Po \\
\hline Naso sp. 2 & & 1 & 0.170 & 4.0 & 4.0 & 4.0 & $\mathrm{Fl}$ \\
\hline \multicolumn{8}{|l|}{ Acropomatidae } \\
\hline Howella sp. & & 12 & 1.585 & 2.5 & 4.0 & 3.5 & Pr, Po \\
\hline \multicolumn{8}{|l|}{ Ammodytidae } \\
\hline Ammodytid sp. & & 4 & 0.722 & 5.5 & 10.0 & 7.8 & Po \\
\hline \multicolumn{8}{|l|}{ Anguilliformes } \\
\hline Anguilliform sp. 1 & & 6 & 1.035 & 6.0 & 11.0 & 8.4 & $\mathrm{Le}$ \\
\hline \multicolumn{8}{|l|}{ Apogonidae } \\
\hline Apogon sp. & & 1 & 0.236 & 3.0 & 3.0 & 3.0 & $\operatorname{Pr}$ \\
\hline Pseudaminae sp. 1 & & 1 & 0.079 & 5.5 & 5.5 & 5.5 & Po \\
\hline \multicolumn{8}{|l|}{ Astronesthidae } \\
\hline Astronestid sp. 1 & & 5 & 1.198 & 10.0 & 17.0 & 12.7 & Po \\
\hline \multicolumn{8}{|l|}{ Bathylagidae } \\
\hline Bathylagid sp. & & 1 & 0.189 & 6.0 & 6.0 & 6.0 & $\operatorname{Pr}$ \\
\hline \multicolumn{8}{|l|}{ Bothidae } \\
\hline Engyrosopon & & 3 & 0.236 & 4.0 & 6.0 & 4.7 & $\mathrm{Pr}, \mathrm{Fl}$ \\
\hline Perissias sp.? & & 1 & 0.171 & 5.0 & 5.0 & 5.0 & $\operatorname{Pr}$ \\
\hline \multicolumn{8}{|l|}{ Bramidae } \\
\hline Brama sp. & & 4 & 0.604 & 3.0 & 4.0 & 3.5 & $\operatorname{Pr}$ \\
\hline \multicolumn{8}{|l|}{ Bregmacerotidae } \\
\hline Bregmaceros atlanticus & 4 & 35 & 5.318 & 2.0 & 13.0 & 3.9 & Pr, Fl, Po \\
\hline Bregmaceros & 5 & 27 & 3.826 & 2.0 & 8.0 & 4.1 & Pr, Fl, Po \\
\hline Bregmaceros nectabanus & 8 & 25 & 2.704 & 3.0 & 12.0 & 6.9 & Pr, Fl, Po \\
\hline \multicolumn{8}{|l|}{ Bythitidae } \\
\hline Brosmophycis marginata & & 2 & 0.310 & 3.5 & 7.0 & 5.3 & $\operatorname{Pr}$ \\
\hline \multicolumn{8}{|l|}{ Callionymidae } \\
\hline Callionymid sp. 1 & & 2 & 0.465 & 2.5 & 4.0 & 3.3 & Po \\
\hline Callionymid sp. 3 & & 1 & 0.270 & 4.0 & 4.0 & 4.0 & Po \\
\hline \multicolumn{8}{|l|}{ Carangidae } \\
\hline Carangid sp. & & 2 & 0.344 & 3.0 & 3.5 & 3.3 & Pr, Po \\
\hline Trachurus sp. & & 1 & 0.122 & 13.0 & 13.0 & 13.0 & Po \\
\hline \multicolumn{8}{|l|}{ Carapidae } \\
\hline Echiodon sp. & & 1 & 0.155 & 9.0 & 9.0 & 9.0 & $\operatorname{Pr}$ \\
\hline \multicolumn{8}{|l|}{ Chamsodontidae } \\
\hline Chamsodon sp. 2 & & 2 & 0.157 & 4.5 & 4.8 & 4.7 & $\mathrm{Fl}$ \\
\hline \multicolumn{8}{|l|}{ Chauliodontidae } \\
\hline Chauliodus sp. & & 3 & 0.517 & 19.0 & 24.0 & 21.0 & Po \\
\hline \multicolumn{8}{|l|}{ Cirrhitidae } \\
\hline Cirrhitid sp. 1 & & 3 & 0.451 & 4.0 & 6.0 & 4.8 & Pr, Po \\
\hline \multicolumn{8}{|l|}{ Coryphaenidae } \\
\hline Coryphaena hippurus & & 5 & 0.582 & 3.0 & 6.5 & 4.7 & Pr, Fl, Po \\
\hline
\end{tabular}


Derichthyidae

Derichthys serpentinus

0.171

$30.0 \quad 30.0 \quad 30.0$

Le

Diodontidae

Diodontid sp. 1

$\begin{array}{lllll}0.189 & 2.5 & 2.5 & 2.5 & \text { Pr }\end{array}$

Evermannellidae

Evermannellid sp.

0.993

$\begin{array}{lll}4.0 & 7.0 \quad 4.9\end{array}$

$\operatorname{Pr}$

Exocoetidae

Exocoetid sp. 1

0.117

$\begin{array}{lll}4.5 & 4.5 \quad 4.5\end{array}$

Po

Gempylidae

Gempylid sp. 1

Gempylus serpens

0.382

$\begin{array}{lll}5.0 & 5.0 \quad 5.0\end{array}$

$\mathrm{Pr}, \mathrm{Fl}$

Gobiidae

Goby sp. 1

0.255

$\begin{array}{lll}5.2 & 5.2 \quad 5.2\end{array}$

$\mathrm{Fl}$

Goby sp. 6

0.122

$\begin{array}{llll}6.5 & 6.5 & 6.5 & \text { Po }\end{array}$

Goby sp. 7

0.465

$\begin{array}{lll}3.5 & 5.5 \quad 4.5\end{array}$

Fl, Po

$\begin{array}{ll}3 & 0.565\end{array}$

$\begin{array}{lll}4.0 & 4.0 \quad 4.0\end{array}$

Po

Gonostomatidae

Cyclothone alba

3

10.496

$\begin{array}{lll}3.5 & 17.0 \quad 7.2\end{array}$

Pr, Fl, Po

Cyclothone sp.

Diplophos sp. 1

1.132

$\begin{array}{lll}5.0 & 20.0 & 12.4\end{array}$

Po

0.463

$\begin{array}{lll}10.0 & 21.0 & 15.5\end{array}$

Pr, Po

Gonostoma elongatum

0.125

$\begin{array}{lll}8.0 & 8.0 \quad 8.0\end{array}$

Po

Gonostoma sp.

0.557

$\begin{array}{lll}5.5 & 10.0 \quad 7.8\end{array}$

Po

Haemulidae

Haemulid spp.

0.500

$\begin{array}{lll}2.0 & 5.0 & 3.7\end{array}$

Pr, Po

Hemiramphidae

Hyporhamphus sp.

0.146

$\begin{array}{lll}5.5 & 5.5 & 5.5\end{array}$

Po

Idiacanthidae

Idiacanthus sp.

0.997

$6.0 \quad 30.0 \quad 11.9$

Pr, Po

Labridae

Cirrhilabrus sp.

0.266

$\begin{array}{lll}3.5 & 3.5 & 3.5\end{array}$

Fl

Julidin sp.

0.157

$4.0 \quad 4.0 \quad 4.0$

Fl

Labrid

0.171

$\begin{array}{lll}4.5 & 4.5 & 4.5\end{array}$

Po

0.310

$\begin{array}{lll}4.2 & 6.5 & 5.4\end{array}$

Po

Labrid sp. 1

0.079

$\begin{array}{lll}10.5 & 10.5 & 10.5\end{array}$

Po

Xyrichthus sp. 2

0.236

$\begin{array}{lll}8.0 & 8.0 \quad 8.0\end{array}$

Po

Lutjanidae

Lutjanid sp. 1

0.189

$\begin{array}{lll}3.5 & 3.5 & 3.5\end{array}$

$\operatorname{Pr}$

Macrouridae

Coryphaenoides sp.

0.377

$\begin{array}{lll}3.0 & 5.5 & 4.3\end{array}$

$\operatorname{Pr}$

Melamphaidae

Melamphaes sinus

Melamphaid sp. 1

0.391

0.197

$8.0 \quad 8.0 \quad 8.0$

Po

Melanocetidae

Melanocetus sp.

0.236

$\begin{array}{lll}5.0 & 5.0 & 5.0\end{array}$

Po

Melanostomiidae

Melanostomiid sp.1

Tactostoma sp.

1

$\begin{array}{lll}2.5 & 2.5 & 2.5\end{array}$

$\operatorname{Pr}$

$3 \quad 0.472$

$4.0 \quad 9.0$

6.2

$\begin{array}{lll}5.5 & 5.5 & 5.5\end{array}$

Pr, Fl, Po

0.123

$\begin{array}{lll}1.0 & 3.8 & 1.8\end{array}$

$\operatorname{Pr}$

Molidae

Ranzania laevis

2

109

18.588

$\begin{array}{llll}4.3 & 9.0 & 6.6 & \mathrm{Pr}, \mathrm{Po}\end{array}$

$5 \quad 0.634$ 
Myctophidae

Benthosema suborbitale

Bolinichthys sp.

Diaphus brachycephalus

Diaphus diadematus

Diaphus pacificus

Diaphus mollis

Diaphus sp. 1

Diaphus sp. 2

Diaphus sp. 3

Diaphus sp. 4

Diaphus sp. 8

Diaphus sp.

Diogenichthys atlanticus

Hygophum proximum

Lampanyctus alatus

Lampanyctus nobilis

Lampanyctinae sp. 1

Lampanyctus sp. 3

Lampadena luminosa

Lampadena urophorus

Lobianchia gemellarii

Myctophid sp. 1

Myctophid sp. 2

Myctophinae sp. 1

Myctophum

Myctophum nitidulum

Myctophum selenops

Notolychnus sp.

Protomyctophum sp.

Stenobrachius sp.

Symbolophorus

Taaningichthys sp.

Triphotorus nigrescens

Triphotorus sp. 1

Myctophid unidents

Nomeidae

Cubiceps pauciradiatus

Psenes pellucidus

6

10

13

7

20

3

5

7

21

3

236

1

9

Notosudidae

Notosudid sp.

Ogcocephalidae

Zalieutes sp. (elater)

Ophidiidae

Brotula sp.

Paralepididae

Lestidiops (ringens)

Magnisudus sp.

Paralepid sp. 1

Pempheridae
15

11

1

1

1

3

2

1

3

3

4

6

2

1

21

1

8

10

4

1

1

3

1

1

1

1

8

8

2

1

2.026

1.955

1.932

0.189

0.600

3.230

0.189

0.189

0.566

0.377

0.266

0.765

0.642

0.449

1.000

1.030

0.377

0.266

2.769

0.079

1.840

1.311

0.620

0.109

0.170

0.414

0.236

0.189

0.079

0.074

1.289

0.302

0.384

0.074

42.916

2.292

0.699

3

3

0.466

0.255

0.236

0.463

0.508

1.274

3

5

\section{5}

14.5

5.9

$12.0 \quad 6.0$

Pr, Fl, Po, Ju

4.0

10.0

5.9

Pr, Fl, Po

$\begin{array}{lll}10.5 & 10.5 \quad 10.5\end{array}$

Pr, Fl, Po

$\begin{array}{lll}3.5 & 9.0 & 4.2\end{array}$

Po

$3.0 \quad 6.0 \quad 4.0$

$\begin{array}{lll}11.0 & 11.0 \quad 11.0\end{array}$

Pr, Fl, Po

Pr, Fl, Po

Po

$\begin{array}{lll}9.5 & 9.5 & 9.5\end{array}$

Po

$\begin{array}{lll}4.5 & 5.0 & 4.7\end{array}$

Fl, Po

$4.0 \quad 7.0 \quad 5.5$

$\begin{array}{lll}5.5 & 5.5 \quad 5.5\end{array}$

$\mathrm{Pr}, \mathrm{Po}$

$3.8 \quad 4.6 \quad 4.1$

Po

Fl, Po

$\begin{array}{lll}4.0 & 8.0 & 4.7\end{array}$

$\mathrm{Fl}$

$\begin{array}{lll}3.0 & 8.0 & 5.4\end{array}$

Pr, Fl, Po

$\begin{array}{lll}2.0 & 4.5 & 3.3\end{array}$

Pr, Fl, Po

$\begin{array}{lll}3.0 & 4.5 & 3.4\end{array}$

$\mathrm{Pr}, \mathrm{Po}$

$\mathrm{Pr}, \mathrm{Fl}$

$\begin{array}{lll}3.0 & 3.5 & 3.3 \\ 3.5 & 3.5 & 3.5\end{array}$

$\mathrm{Pr}$

Pr, Fl, Po

$$
\mathrm{Pr}
$$

$\begin{array}{lll}2.5 & 2.5 & 2.5\end{array}$

$\mathrm{Fl}, \mathrm{Po}$

$\begin{array}{lll}4.0 & 6.0 \quad 4.8\end{array}$

Pr, Po

Pr, Po

$\begin{array}{lll}3.0 & 4.5 & 3.8\end{array}$

$\begin{array}{lll}3.0 & 3.0 & 3.0\end{array}$

$\mathrm{Pr}$

$\mathrm{Pr}$

Pr, Fl, Po

$\begin{array}{lll}5.0 & 7.0 & 5.7\end{array}$

$4.0 \quad 4.0 \quad 4.0$

$\operatorname{Pr}$

$\begin{array}{lll}7.5 & 7.5 & 7.5\end{array}$

$9.0 \quad 9.0 \quad 9.0$

Po

Po

$\begin{array}{lll}16.0 & 16.0 \quad 16.0\end{array}$

$\mathrm{Po}$

$\begin{array}{lll}4.0 & 8.5 & 5.9\end{array}$

Pr, Fl, Po

$\begin{array}{lll}6.5 & 20.0 & 13.3\end{array}$

$\mathrm{Fl}, \mathrm{Po}, \mathrm{Ju}$

$\begin{array}{lll}5.0 & 10.0 & 7.3\end{array}$

Fl, Po

$\begin{array}{lll}10.0 & 10.0 & 10.0\end{array}$

Po

$\begin{array}{lll}2.5 & 7.0 & 4.3\end{array}$

Pr, Fl, Po

$\begin{array}{lll}3.0 & 11.0 & 4.6\end{array}$

Pr, Fl, Po

$\begin{array}{lll}4.5 & 5.0 & 4.8\end{array}$

$\mathrm{Fl}$

$9.0 \quad 9.0 \quad 9.0$

$\operatorname{Pr}$

$\begin{array}{llll}2.0 & 2.0 & 2.0 & \operatorname{Pr}\end{array}$

$\begin{array}{lll}5.5 & 8.0 \quad 6.3\end{array}$

Pr

$\begin{array}{lll}6.5 & 16.0 & 10.5\end{array}$

Po

$\begin{array}{llll}5.5 & 9.0 & 6.7 & \mathrm{Pr}, \mathrm{Fl}\end{array}$

$\begin{array}{lll}5.0 & 12.0 \quad 7.3\end{array}$

Pr, Po 
Pempherid sp. 1

Percophidae

Osopsaron sp.

Percophid sp. 1

Acanthaphritis sp.

Phosichthyidae

Phosichthyid sp. 1

Vinciguerria lucetia

Pomacanthidae

Centropyge sp.

Priacanthidae

Cookeolus japonicus

Samaridae

Samarid sp. 1

Scaridae

Scarid sp. 1

Scarid sp. 6

Scombridae

Auxis sp.

Scomberomorus sp.

Thunnus sp.

Scopelarchiidae

Scopelarchus sp. 1

Scorpaenidae

Scorpaenid Morph B sp.2

Serranidae

Anthias sp. 2

Anthiine sp.

Sphyraenidae

Sphyraena sp. 1

Sternoptychidae

Argyropelecus lychnus

Argyropelecus sladeni

Argyropelecus sp.

Synodontidae

Synodus (lucioceps)

Trachinocephalus myops

Tetraodontidae

Tetraodontid sp. 1

Trichiuridae

Trichiurid sp. 1

Unidentified
2

1

0.377

0.155

0.155

0.249

1.975

0.267

0.171

0.074

0.406

0.171

0.255

0.315

1.476

0.885

0.122

0.415

0.266

0.729

0.222

1.171

0.698

5

(1)

0.310

0.079

0.079

0.364

5.062

$\begin{array}{lll}5.5 & 6.5 & 6.0 \\ 7.0 & 7.0 & 7.0 \\ 7.0 & 7.0 & 7.0\end{array}$

$\begin{array}{lll}5.5 & 7.0 & 6.3\end{array}$

$\begin{array}{lll}4.5 & 16.0 & 8.4\end{array}$

$\mathrm{Fl}$

$\begin{array}{lll}3.5 & 4.0 \quad 3.8\end{array}$

$\mathrm{Fl}, \mathrm{Po}$

Pr, Po

$8.0 \quad 8.0 \quad 8.0$

Po

$6.0 \quad 6.0 \quad 6.0$

$\operatorname{Pr}$

$\begin{array}{lll}4.0 & 4.0 \quad 4.0\end{array}$

Fl

$\begin{array}{lll}6.0 & 6.0 \quad 6.0\end{array}$

Po

$\begin{array}{llll}5.0 & 5.0 & 5.0 & \mathrm{Fl}\end{array}$

$4.0 \quad 5.0 \quad 4.5$

$\mathrm{Fl}$

$4.0 \quad 6.0 \quad 5.0 \quad$ Pr, Fl, Po

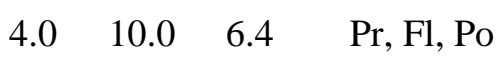

$\begin{array}{llll}6.5 & 6.5 & 6.5 & \text { Po }\end{array}$

$\begin{array}{lll}4.0 & 9.5 & 7.2\end{array}$

Fl, Po

$\begin{array}{lll}5.0 & 5.0 & 5.0\end{array}$

Po

$\begin{array}{llll}3.5 & 9.5 & 6.7 & \mathrm{Pr}, \mathrm{Po}\end{array}$

$\begin{array}{llll}7.5 & 20.0 & 11.8 & \text { Po, Ju }\end{array}$

$\begin{array}{llll}5.0 & 9.0 & 7.5 & \mathrm{Fl}, \mathrm{Po}\end{array}$

$\begin{array}{llll}6.0 & 9.0 & 7.3 & \mathrm{Fl}, \mathrm{Po}\end{array}$

$\begin{array}{lllccc}2 & 0.310 & 8.5 & 11.0 & 9.7 & \text { Fl } \\ 1 & 0.079 & 8.0 & 8.0 & 8.0 & \text { Pr }\end{array}$

62 $\begin{array}{llll}8.0 & 8.0 & 8.0 & \text { Po }\end{array}$

$\begin{array}{llll}6.5 & 7.0 & 6.8 & \mathrm{Pr}, \mathrm{Fl}\end{array}$

$2.9 \quad 7.5 \quad 4.6 \quad$ Pr, Fl, Po
Grand Total

Total no. families

Total no. species/taxa
156.980

58

127 
Appendix C: Summary of families and species, density (larvae $100 \mathrm{~m}^{-3}$ ), minimum, maximum and average size, and developmental stages recorded at the Walters Shoal seamount.

\begin{tabular}{|c|c|c|c|c|c|c|c|}
\hline & \multirow[b]{2}{*}{$\begin{array}{c}\text { Overall } \\
\text { rank }\end{array}$} & \multirow[b]{2}{*}{ No. } & \multirow[b]{2}{*}{ larvae $100 \mathrm{~m}^{-3}$} & \multicolumn{3}{|c|}{ Size (mm) } & \multirow[b]{2}{*}{$\begin{array}{c}\text { Dev } \\
\text { stages }\end{array}$} \\
\hline & & & & Min & $\operatorname{Max}$ & Ave & \\
\hline \multicolumn{8}{|l|}{ Gonostomatidae } \\
\hline Cyclothone pseudopallida & 1 & 49 & 3.306 & 6.0 & 20.0 & 12.3 & Po \\
\hline Gonostoma sp. & & 1 & 0.155 & 4.2 & 4.2 & 4.2 & $\mathrm{Fl}$ \\
\hline \multicolumn{8}{|l|}{ Idiacanthidae } \\
\hline Idiacanthus sp. & 7 & 3 & 0.252 & 9.0 & 17.0 & 12.0 & $\operatorname{Pr}$ \\
\hline \multicolumn{8}{|l|}{ Melamphaidae } \\
\hline Melamphaes sp. 1 & 3 & 14 & 0.921 & 3.0 & 6.0 & 3.9 & Pr, Fl, Po \\
\hline Melamphaes sp. 2 & & 1 & 0.104 & 8.0 & 8.0 & 8.0 & Po \\
\hline \multicolumn{8}{|l|}{ Melanocoetidae } \\
\hline Melanocoetid sp. & & 1 & 0.140 & 4.0 & 4.0 & 4.0 & $\mathrm{Fl}$ \\
\hline \multicolumn{8}{|l|}{ Myctophidae } \\
\hline Benthosema suborbitale & & 1 & 0.140 & 3.5 & 3.5 & 3.5 & $\operatorname{Pr}$ \\
\hline Diaphus brachycephalus & & 1 & 0.111 & 6.0 & 6.0 & 6.0 & Po \\
\hline Diaphus sp. 2 & & 1 & 0.140 & 8.5 & 8.5 & 8.5 & Po \\
\hline Diogenichthys atlanticus & & 2 & 0.192 & 3.0 & 4.5 & 3.8 & $\mathrm{Pr}, \mathrm{Fl}, \mathrm{Po}$ \\
\hline Hygophum proximum & 2 & 20 & 1.430 & 3.0 & 6.0 & 4.8 & Fl, Po \\
\hline Lampadena sp. & 6 & 3 & 0.261 & 5.0 & 9.5 & 7.2 & Po \\
\hline Lampanyctus sp. 1 & & 1 & 0.104 & 3.5 & 3.5 & 3.5 & $\operatorname{Pr}$ \\
\hline Lampanyctus sp. 2 & & 1 & 0.104 & 4.0 & 4.0 & 4.0 & $\operatorname{Pr}$ \\
\hline Lampanyctus sp. 3 & 3 & 2 & 0.201 & 3.0 & 3.0 & 3.0 & $\operatorname{Pr}$ \\
\hline Lampanyctus sp. 9 & 9 & 3 & 0.216 & 3.0 & 5.8 & 4.8 & $\mathrm{Pr}, \mathrm{Fl}$ \\
\hline Myctophid sp. & & 1 & 0.104 & 5.0 & 5.0 & 5.0 & $\mathrm{Fl}$ \\
\hline Myctophum nitidulum & & 1 & 0.104 & 4.5 & 4.5 & 4.5 & $\mathrm{Fl}$ \\
\hline Scopelopsis multipunctatis & & 1 & 0.104 & 5.0 & 5.0 & 5.0 & $\mathrm{Fl}$ \\
\hline \multicolumn{8}{|l|}{ Notosudidae } \\
\hline Scopelosaurus sp. & 5 & 4 & 0.294 & 4.0 & 14.0 & 7.1 & Pr, Po \\
\hline \multicolumn{8}{|l|}{ Phosichthyidae } \\
\hline Vinciguerria sp. & & 1 & 0.051 & 7.0 & 7.0 & 7.0 & $\mathrm{Fl}$ \\
\hline \multicolumn{8}{|l|}{ Sphyraenidae } \\
\hline Sphyraena sp. & & 1 & 0.096 & 3.0 & 3.0 & 3.0 & $\operatorname{Pr}$ \\
\hline \multicolumn{8}{|l|}{ Sternoptychidae } \\
\hline Argyropelecus lychnus & 8 & 3 & 0.220 & 8.0 & 9.0 & 8.7 & Po \\
\hline Argyropelecus sladeni & 4 & 4 & 0.308 & 6.0 & 9.0 & 7.8 & $\mathrm{Fl}, \mathrm{Po}$ \\
\hline Unidentified & & 9 & 0.535 & 3.0 & 5.0 & 4.1 & $\mathrm{Pr}, \mathrm{Fl}$ \\
\hline Grand Total & & 129 & 9.598 & & & & \\
\hline Total no. families & & 9 & & & & & \\
\hline Total no. species/taxa & & 24 & & & & & \\
\hline
\end{tabular}


a)

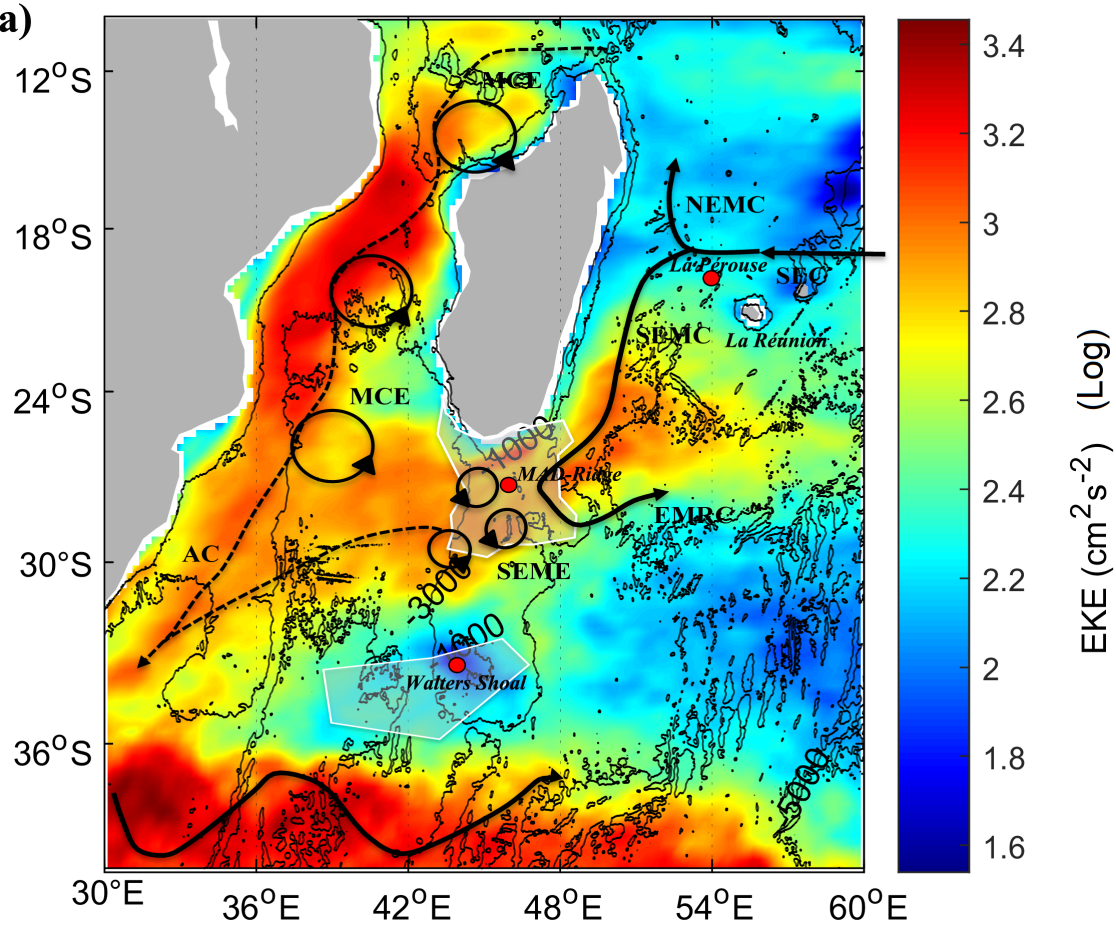



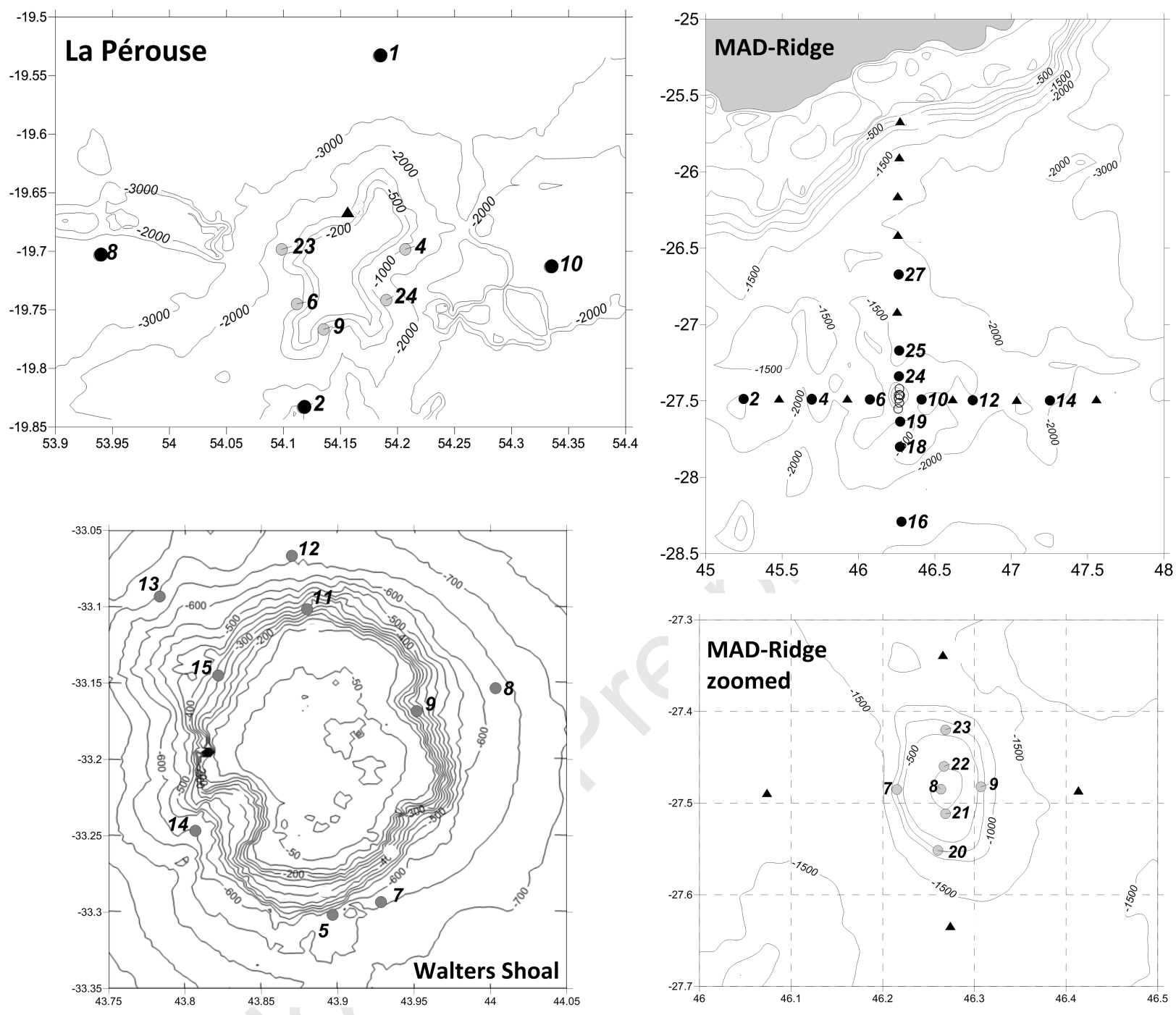


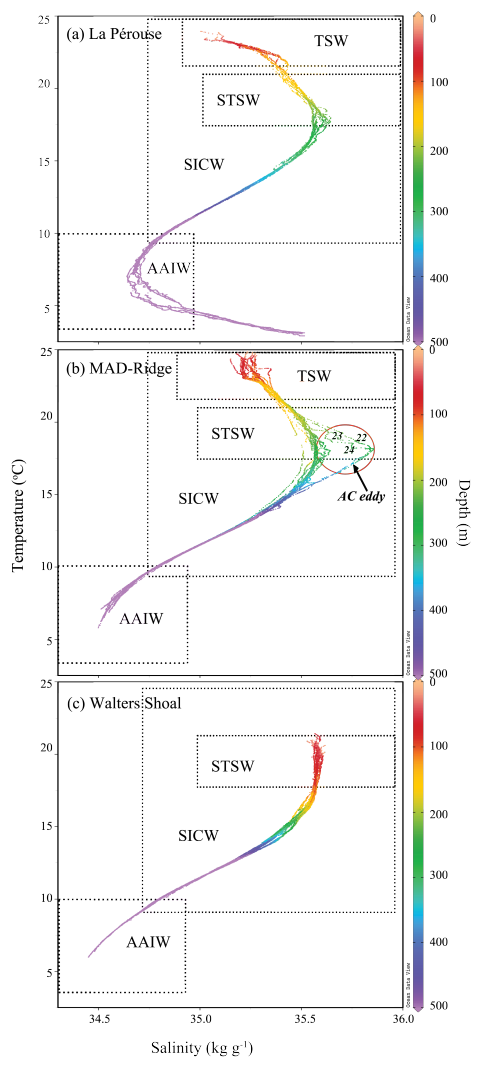



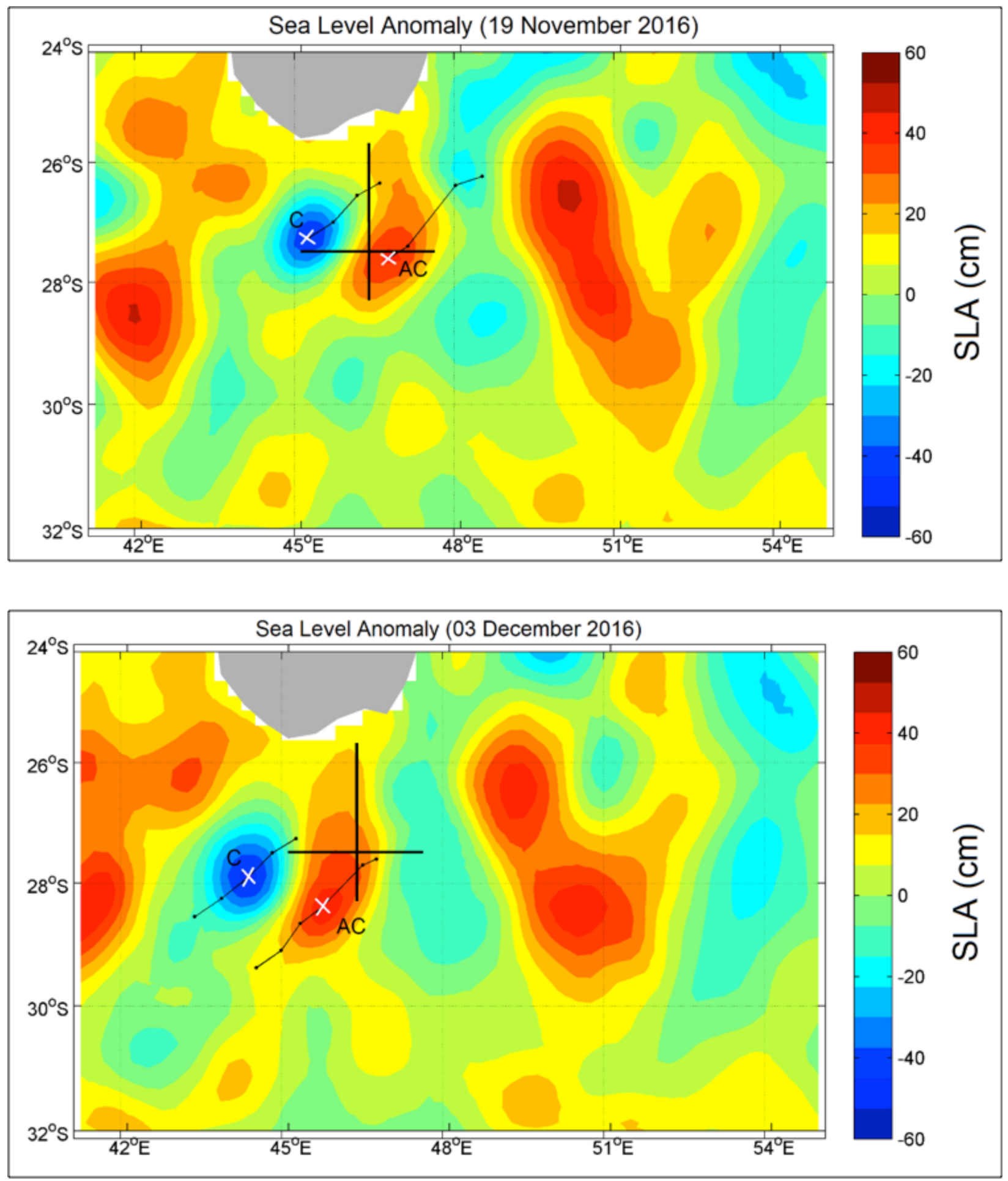
OFF ON

20

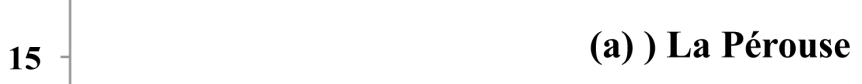

10

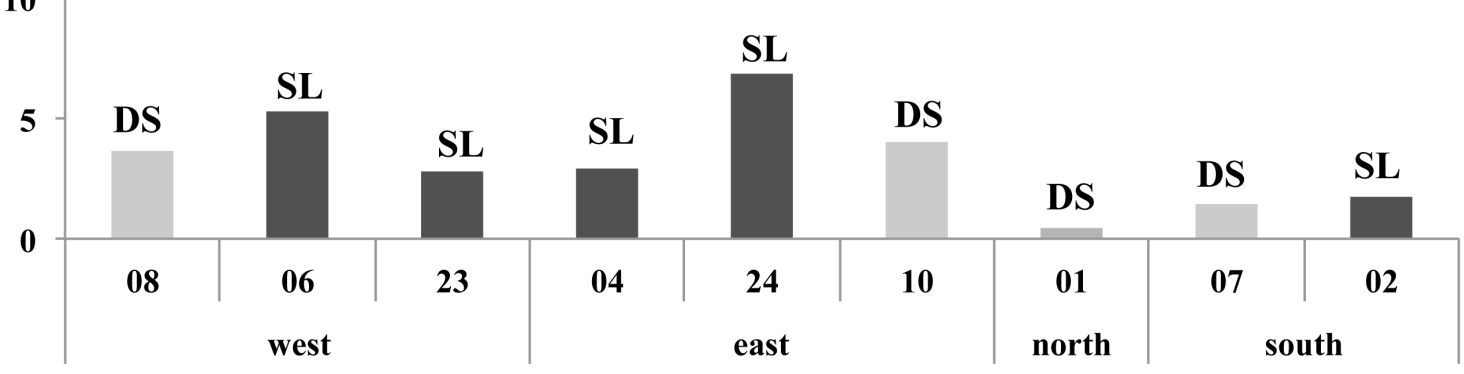

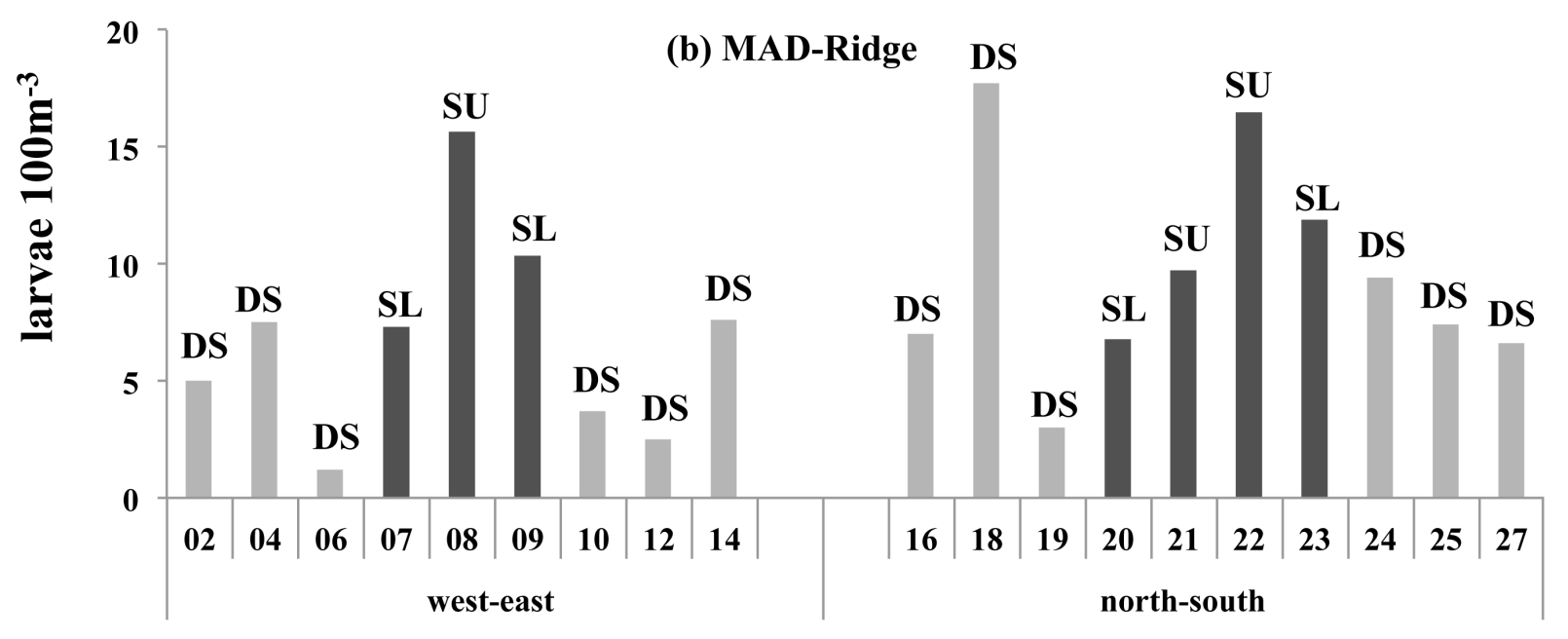

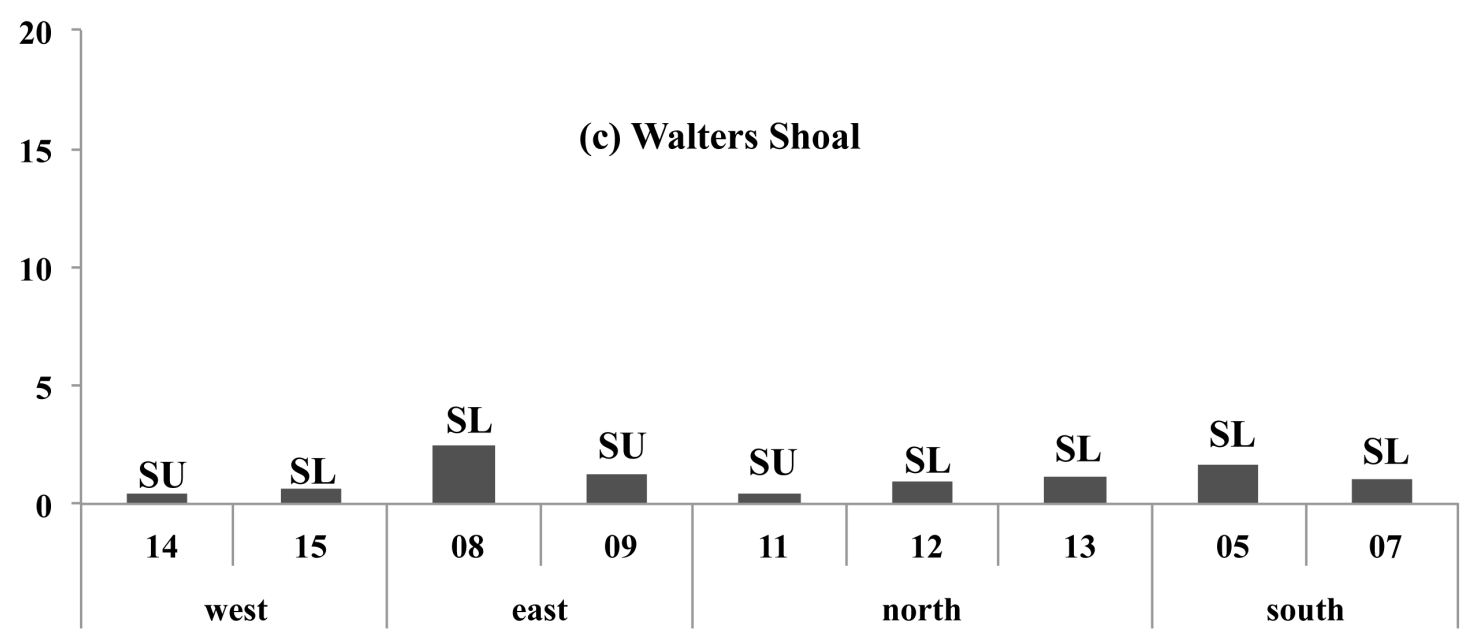

Station 
(a)

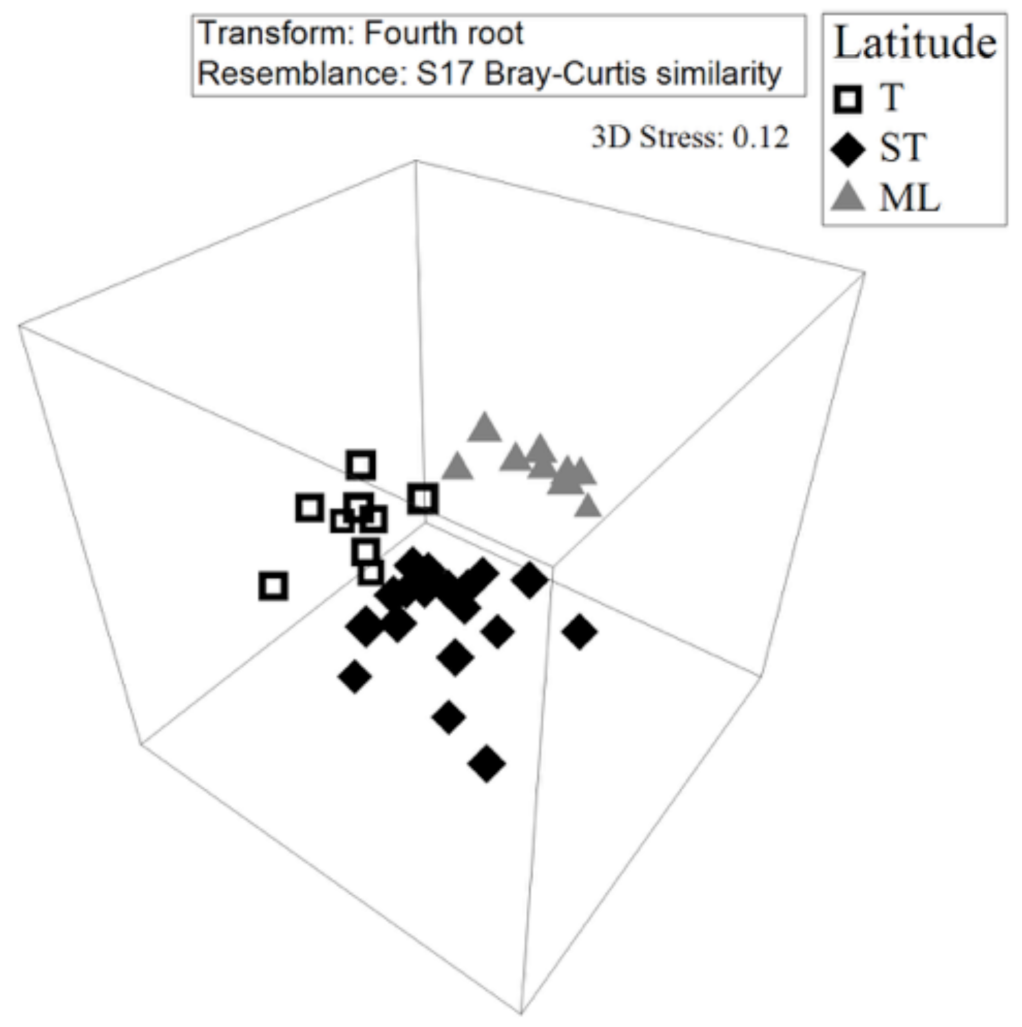

(b)

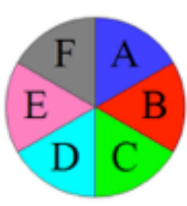

A. Cyclothone pseudopallida 0 - 2

B. Myctophid unidents 0-2

C. Cyclothone alba 0 - 2

D. Ranzania laevis 0 - 2

E. Hygophum proximum $0-2$

F. Melamphaes sp. 1 0 - 1

WS14

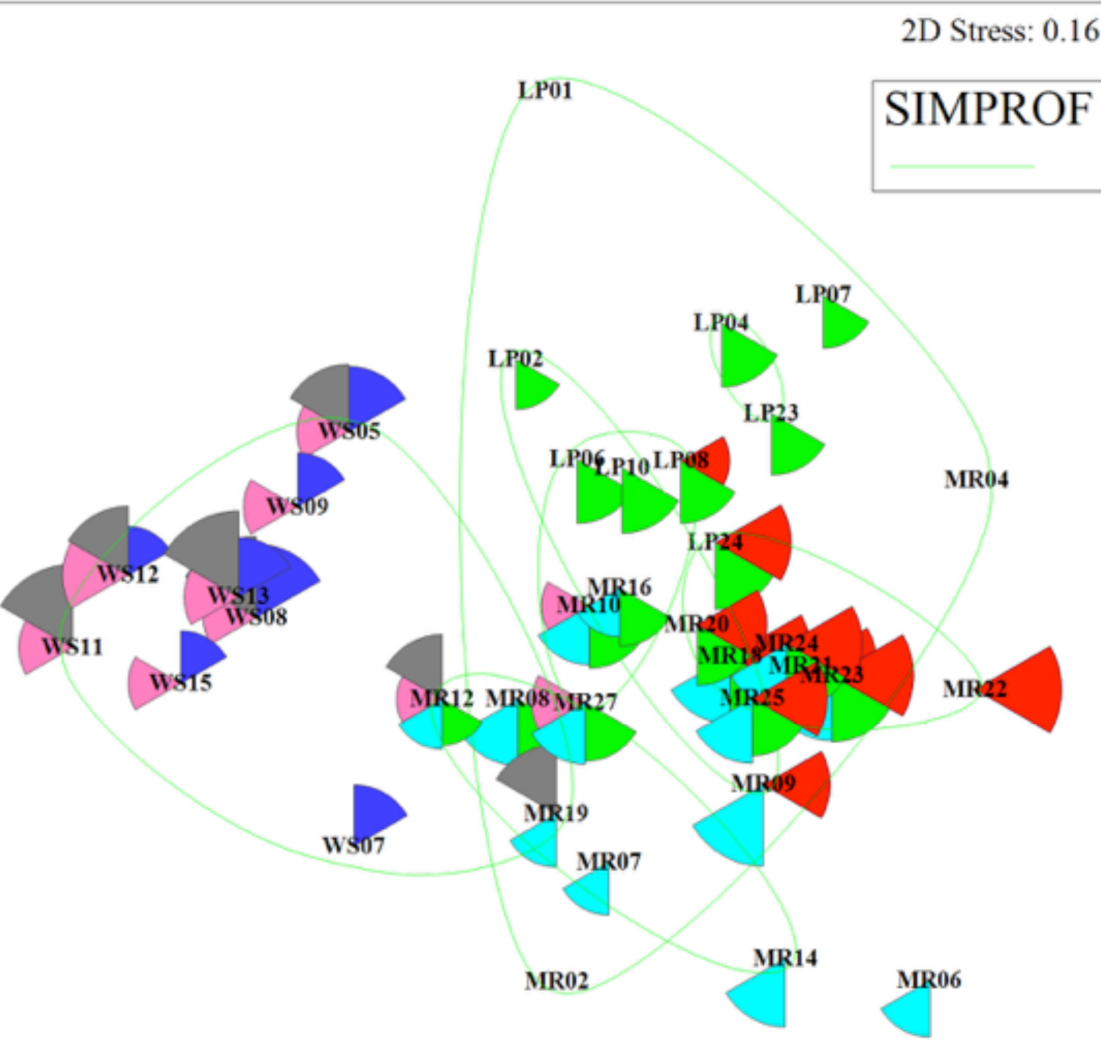




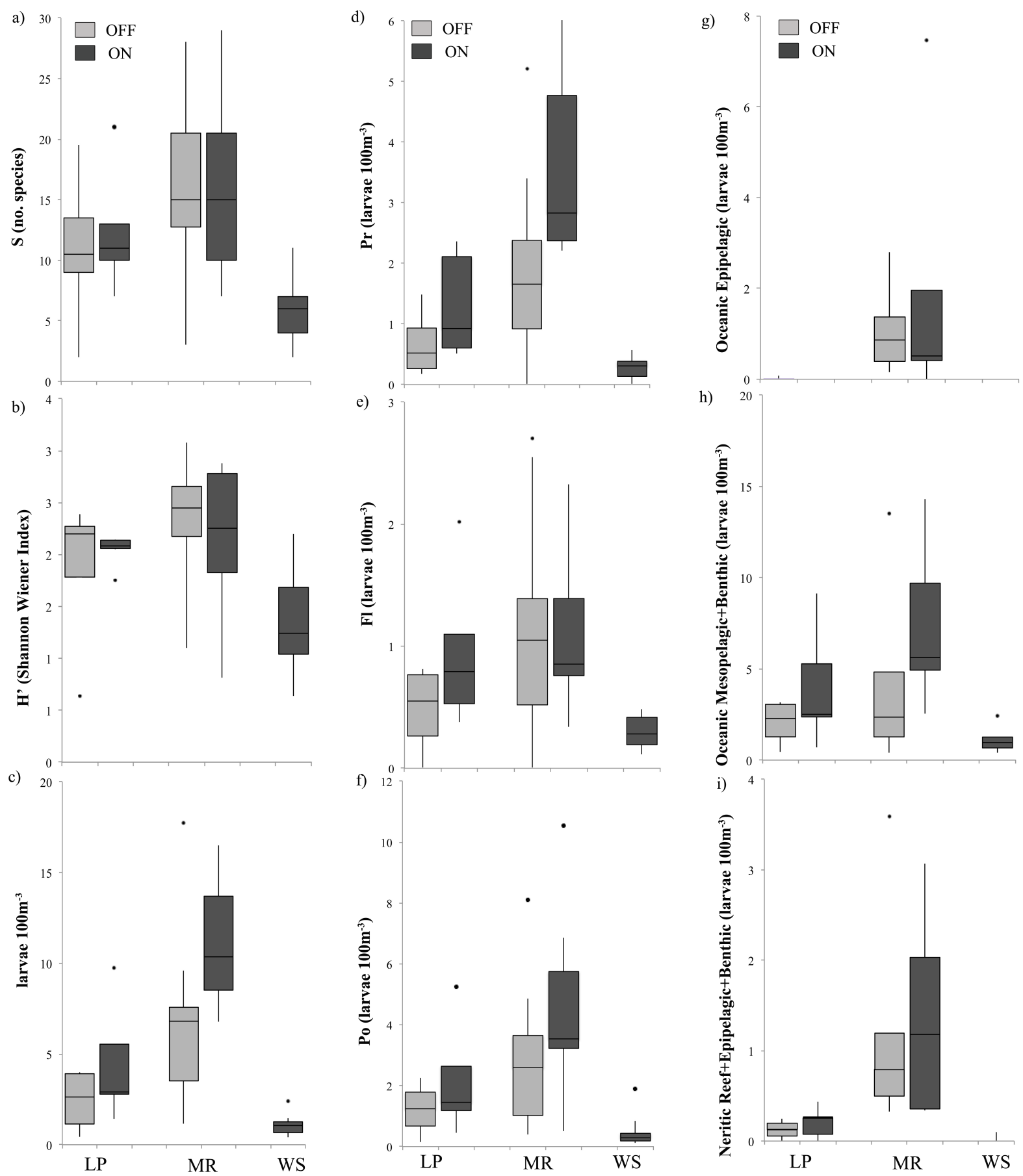




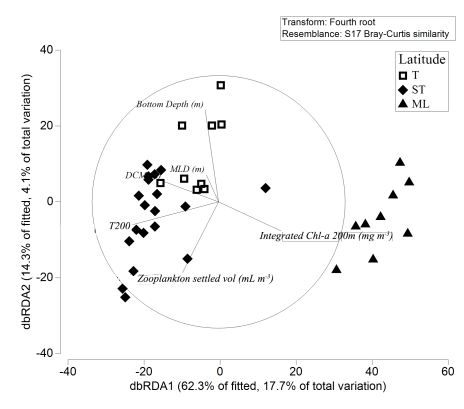




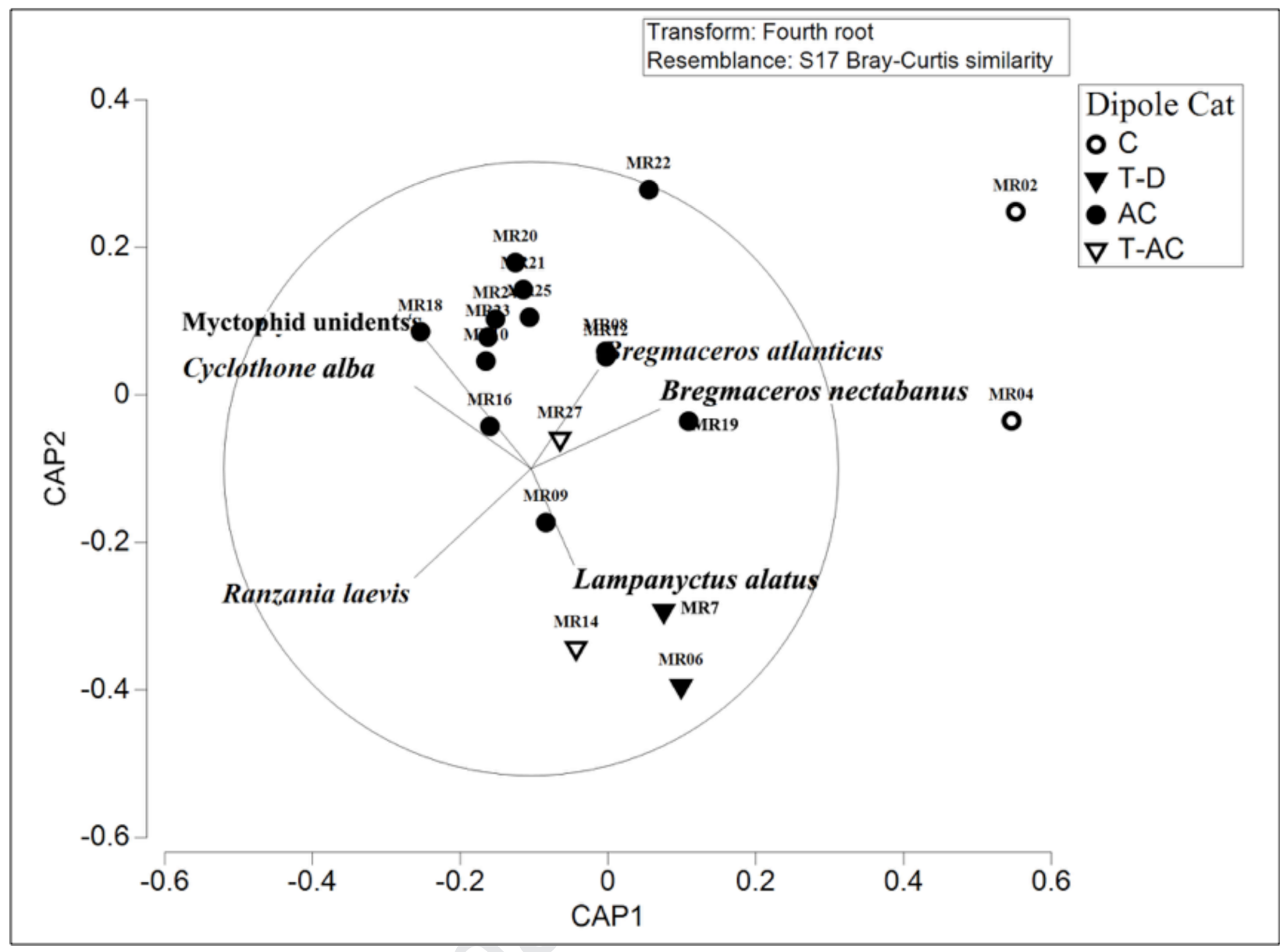




\section{Declaration of interests}

चThe authors declare that they have no known competing financial interests or personal relationships that could have appeared to influence the work reported in this paper.

$\square$ The authors declare the following financial interests/personal relationships which may be considered as potential competing interests: 